\title{
ROA-beroepenclassificatie 1990
}

Citation for published version (APA):

Dekker, R., de Grip, A., \& van de Loo, P. J. E. (1990). ROA-beroepenclassificatie 1990. Researchcentrum voor Onderwijs en Arbeidsmarkt, Faculteit der Economische Wetenschappen. ROA Working Papers No. 9 https://doi.org/10.26481/umarow.1990009

Document status and date:

Published: 01/01/1990

DOI:

10.26481/umarow.1990009

Document Version:

Publisher's PDF, also known as Version of record

\section{Please check the document version of this publication:}

- A submitted manuscript is the version of the article upon submission and before peer-review. There can be important differences between the submitted version and the official published version of record.

People interested in the research are advised to contact the author for the final version of the publication, or visit the DOI to the publisher's website.

- The final author version and the galley proof are versions of the publication after peer review.

- The final published version features the final layout of the paper including the volume, issue and page numbers.

Link to publication

\footnotetext{
General rights rights.

- You may freely distribute the URL identifying the publication in the public portal. please follow below link for the End User Agreement:

www.umlib.nl/taverne-license

Take down policy

If you believe that this document breaches copyright please contact us at:

repository@maastrichtuniversity.nl

providing details and we will investigate your claim.
}

Copyright and moral rights for the publications made accessible in the public portal are retained by the authors and/or other copyright owners and it is a condition of accessing publications that users recognise and abide by the legal requirements associated with these

- Users may download and print one copy of any publication from the public portal for the purpose of private study or research.

- You may not further distribute the material or use it for any profit-making activity or commercial gain

If the publication is distributed under the terms of Article $25 \mathrm{fa}$ of the Dutch Copyright Act, indicated by the "Taverne" license above, 
ROA-BEROEPENCLASSIFICATIE 1990

ROA-W-199019

R.J.P. Dekker, A. de Grip,

P.J.E. van de Loo

RESEARCHCENTRUM VOOR ONDERWIJS EN ARBEIDSMARKT

Faculteit der Economische Wetenschappen

Rijksuniversiteit Limburg

Maastricht, december 1990 


\section{CIP-GEGEVENS KONINKLIJKE BIBLIOTHEEK, DEN HAAG}

Dekker, R.J.P.

ROA-beroepenclassificatie 1990 / R.J.P. Dekker, A. de Grip, P.J.E. van de Loo. - Maastricht: Researchcentrum voor Onderwijs en Arbeidsmarkt, Faculteit der Economische Wetenschappen, Rijksuniversiteit Limburg. - (Werkdocument $=$ working paper $/$ Researchcentrum voor Onderwijs en Arbeidsmarkt, ISSN 0922-4645; 1990/9)

Met lit. opg.

ISBN 90-5321-054-7 in spiraalband

Trefw.: beroepenclassificatie. 


\section{INHOUDSOPGAVE}

bladzijde

VERANTWOORDING

SAMENVATTING

1. INLEIDING

2. OPZET ROA-BEROEPENCLASSIFICATIE

2.1. Methodiek ROA-Beroepenclassificatie

2.2. Structuur ROA-Beroepenclassificatie

3. IMPLICATIES ROA-BEROEPENCLASSIFICATIE VOOR

HET INFORMATIESYSTEEM ONDERWIJS-ARBEIDSMARKT 14

3.1. Inleiding 14

3.2. Omvang en samenstelling ROA-beroepsklassen $\quad 14$

3.3. Enkele arbeidsmarktindicatoren 24

3.3.1. Sexespecifieke beroepssegregatie 24

3.3.2. Opleidingenspreiding 25

3.3.3. Branchespreiding 29

4. BESLUIT

$\begin{array}{ll}\text { LITERATUUR } & 36\end{array}$

BIJLAGE 1: ROA-BEROEPENCLASSIFICATIE 1990

BIJLAGE 2: KOPPELSCHEMA TUSSEN CBS- EN ROA-BEROEPENCODES 48

BIJLAGE 3: AANTAL WERKZAME PERSONEN IN 1985 NAAR GESLACHT EN

CBS- EN ROA-BEROEPSKLASSEN 50

BIJLAGE 4: AANTAL WERKZAME PERSONEN IN 1985 NAAR OPLEIDINGSNIVEAU EN CBS- EN ROA-BEROEPSKLASSEN

BIJLAGE 5: GINI-HIRSCHMAN COËFFICIËNTEN VOOR DE OPLEIDINGENSPREIDING NAAR CBS- EN ROA-BEROEPSKLASSEN

BIJLAGE 6: HETEROGENE CBS-BEROEPSKLASSEN MET BIJBEHORENDE ROA-BEROEPSKLASSEN EN ONDERLIGGENDE CBS-BEROEPSGROEPEN 62

BIJLAGE 7: ROA-BEDRIJFSSECTOREN

BIJLAGE 8: GINI-HIRSCHMAN COËFFICIËNTEN VOOR DE BRANCHESPREIDING NAAR CBS- EN ROA-BEROEPSKLASSEN 64

BIJLAGE 9: ROA-OPLEIDINGSTYPEN 


\section{VERANTWOORDING}

De in dit werkdocument gepresenteerde ROA-Beroepenclassificatie is tot stand gekomen in het kader van de verdere ontwikkeling van het informatiesysteem onderwijs-arbeidsmarkt van het Researchcentrum voor Onderwijs en Arbeidsmarkt (ROA). Tot op heden heeft het ROA voor het presenteren van arbeidsmarktgegevens en -prognoses per beroepsklasse gebruik gemaakt van de CBS-Beroepenclassificatie. De door het CBS onderscheiden beroepsklassen komen echter niet in voldoende mate overeen met de op de arbeidsmarkt bestaande segmentering. Daarom heeft het ROA nieuwe beroepsklassen geconstrueerd, die wat betreft de opleidingsachtergrond van de beroepsbeoefenaren meer homogeen zijn dan de huidige CBS-beroepsklassen. Beroepsgroepen met gelijksoortige onderwijsprofielen worden daarbij verondersteld van eenzelfde arbeidsmarktsegment deel uit te maken.

Dit werkdocument kan worden opgevat als een vervolg op het werkdocument 'clustering occupational classes by educational structure' (De Grip, Groot en Heijke, 1987). De resultaten van deze clusteranalyse zijn het uitgangspunt geweest bij het hergroeperen van de ruim 300 CBS-beroepsgroepen naar 93 ROA-beroepsklassen. Door een te hoog aggregatieniveau van de gehanteerde opleidingsindeling ( $\mathrm{SOI} 3 \mathrm{e}$ digit), konden bij die clusteranalyse een aantal (met name technische) beroepsdeelmarkten, niet (verder) worden onderscheiden. Voor het construeren van de ROA-Beroepenclassificatie 1990 is derhalve gebruik gemaakt van enkele aanvullende arbeidsmarkttheoretische en beroepenkundige criteria, evenals een aantal statistische randvoorwaarden.

De studie naar de ROA-Beroepenclassificatie 1990 is, onder leiding van dr. A. de Grip, door drs. R.J.P. Dekker en drs. P.J.E. van de Loo uitgevoerd. Daarnaast hebben drs. L.F.M. Groot en drs. R.K.W. van der Velden aan de totstandkoming van deze beroepenclassificatie een bijdrage geleverd. 



\section{SAMENVATTING}

In dit werkdocument wordt de ROA-Beroepenclassificatie 1990 gepresenteerd, welke is gebaseerd op een clusteranalyse van de beroepsgroepen, die door het CBS lop het driecijferige niveau) worden onderscheiden. Het doel van het hergroeperen van de CBS-beroepsgroepen is te komen tot beroepsklassen, die een beter inzicht geven in de in de praktijk bestaande beroepssegmenten op de arbeidsmarkt. De opleidingsachtergrond van de beroepsbeoefenaren vormt het uitgangspunt bij deze clusteranalyse. De achterliggende gedachte daarbij is dat de beroepsgroepen met dezelfde onderwijsprofielen tot eenzelfde arbeidsmarktsegment behoren.

$\mathrm{Na}$ een inleidend hoofdstuk, waarin ondermeer de problematiek rondom het gebruik van de huidige CBS-Beroepenclassificatie in het kort uiteen wordt gezet, volgt in het tweede hoofdstuk de opzet van de ROA-Beroepenclassificatie. Daarin wordt enerzijds ingegaan op de methodiek op grond waarvan de beroepenclassificatie is geconstrueerd (in casu de minimale variantie clustermethode van Ward, aangevuld met enkele arbeidsmarkttheoretische en beroepenkundige criteria, evenals een aantal statistische randvoorwaarden). Anderzijds wordt de hiërarchische structuur van de beroepenclassificatie, die uit vier analyseniveaus bestaat, toegelicht. In het derde hoofdstuk worden de implicaties van de ROA-Beroepenclassificatie voor het informatiesysteem onderwijs-arbeidsmarkt geanalyseerd. Eerst wordt daarbij een vergelijking gemaakt tussen de omvang en de samenstelling van de beroepsklassen, zoals die in beide indelingen worden onderscheiden. Daarna worden de beide classificaties met elkaar vergeleken met behulp van enkele arbeidsmarktindicatoren: sexe-segregatie, opleidingenspreiding en branchespreiding. Tenslotte zijn een aantal bijlagen bijgevoegd. De eerste bijlage heeft betrekking op de in de ROA-Beroepenclassificatie onderscheiden beroepencodes en beroepsnamen, onderverdeeld naar de vier onderscheiden analyseniveaus, te weten de beroepssectoren, -takken, -segmenten en -klassen. De tweede bijlage betreft de vertaalsleutel van de ROA-beroepsklassen naar de CBS-beroepsgroepen. De overige bijlagen bevatten grotendeels kwantitatieve gegevens over enkele arbeidsmarktkenmerken voor zowel de CBS-, als de ROA-beroepsklassen. 
, 


\section{INLEIDING}

Arbeidsmarktinformatie over beroepen neemt, naast de informatie over opleidingen, een centrale plaats in binnen het ROA-informatiesysteem onderwijs-arbeidsmarkt en de daaruit aan het informatiesysteem I-See! ${ }^{1}$ toegeleverde arbeidsmarktinformatie. Zowel bij de historische data en arbeidsmarktindicatoren, als bij de werkgelegenheids- en vervangingsvraagprognoses heeft de arbeidsmarktinformatie over beroepen tot op heden voor het overgrote deel betrekking op de in de CBS-Beroepenclassificatie (1984) onderscheiden 82 beroepsklassen. Een groot nadeel van deze beroepenclassificatie is de vanuit arbeidsmarktoogpunt nogal eens ongelukkige samenvoeging van beroepsgroepen. Zo wordt bijvoorbeeld op het niveau van de beroepsklassen het onderscheid tussen beroepen op MBO- en HBO-niveau en beroepen, waarvoor wetenschappelijk onderwijs is vereist niet gemaakt. Dit maakt het bijvoorbeeld onmogelijk om op dit aggregatieniveau een onderscheid te maken tussen verpleegkundigen en artsen. Bovendien is de beroepsklassenindeling erg onevenwichtig: sommige beroepsklassen zijn vrij specifiek, terwijl andere juist zeer globaal zijn geclassificeerd.

Het is helaas niet mogelijk uit te wijken naar het lagere aggregatieniveau van beroepsgroepen ${ }^{2}$, omdat de steekproefomvang van belangrijke gegevensbronnen, zoals de Arbeidskrachtentellingen en de Enquête Beroepsbevolking niet toereikend is om op dit lage aggregatieniveau informatie te geven over bijvoorbeeld de leeftijdsopbouw van de beroepsbeoefenaren, of de spreiding over bedrijfssectoren.

Het doel van de CBS-Beroepenclassificatie is de beroepen te groeperen naar de aard van het uitgeoefende beroep. Het criterium 'aard van de werkzaamheden' is echter te weinig operationeel gemaakt (zie Bakker, Den Dulk, Jonker en Oud, 1989). In feite kan de classificatie dan ook bestempeld worden als een administratieve classificatie (zie Sanderson, 1987 en De Grip, Groot en Heijke, 1991). Voor het verstrekken van relevante arbeidsmarktinformatie is het derhalve noodzakelijk tot een functionele classificatie te komen.

Bij een arbeidsmarkttheoretische onderbouwing van een beroepenclassificatie moet de 'afschotting' tussen (beroeps)deelmarkten het centrale uitgangspunt zijn. Ongetwijfeld vormen

1. I-See! staat voor Information System on Education and Employment. Ten behoeve van de arbeidsmarktmodule van dit geautomatiseerde informatiesysteem, dat is gericht op de studie- en beroepskeuzevoorlichting, levert het ROA informatie over de actuele en toekomstige arbeidsmarktkenmerken en -perspectieven van circa zestig opleidingstypen en tachtig beroepsklassen.

2. Het Centraal Bureau voor de Statistiek onderscheidt circa 320 beroepsgroepen. 
de (feitelijke) opleidingskwalificaties van de beroepsbeoefenaren een belangrijk criterium voor de opdeling van de arbeidsmarkt in (beroeps)deelmarkten ${ }^{3}$.

In deze studie wordt een alternatief gepresenteerd voor de beroepsklassenindeling van de CBSBeroepenclassificatie 1984. Deze ROA-Beroepenclassificatie 1990 zal komend jaar als uitgangspunt fungeren voor de invulling van de beroepeninformatie in het ROAinformatiesysteem onderwijs-arbeidsmarkt en de daaruit afgeleide beroepeninformatie in de arbeidsmarktmodule van I-See! 1991.

In plaats van de 82 in de CBS-Beroepenclassificatie onderscheiden beroepsklassen, onderscheidt de ROA-classificatie 93 beroepsklassen. Het centrale indelingscriterium bij de ROA-classificatie is, zoals hierboven werd aangegeven, de opleidingsachtergrond van de beroepsbeoefenaren. Daarnaast is ook getracht te komen tot een meer evenwichtige celvulling. De in de ROAclassificatie onderscheiden beroepsklassen zijn gebaseerd op een hergroepering van de CBSberoepsgroepen. Dit maakt het mogelijk gebruik te blijven maken van de beroepsgroepeninformatie uit de Arbeidskrachtentellingen en de Enquête Beroepsbevolking.

Eerst zijn deze beroepsgroepen met behulp van een clusteranalyse op basis van de opleidingsrichting van de beroepsbeoefenaren in 14 clusters samengevoegd. Deze 14 clusters zijn vervolgens op basis van het opleidingsniveau, de meer specifieke opleidingsrichting, de aard van de werkzaamheden en het arbeidsterrein herleidt tot de genoemde 93 beroepsklassen.

De beroepsklassenindeling is op hiërarchische wijze gestructureerd hetgeen tot uiting komt in een 4-cijferige code, waarbij iedere digit een specifieke betekenis heeft. Op basis van de vakrichting van de werkenden kunnen achtereenvolgens 10 beroepssectoren en 27 beroepstakken worden onderscheiden. Een verdere opdeling naar opleidingsniveau leidt tot 48 beroepssegmenten, die tenslotte weer worden opgesplitst in 93 beroepsklassen.

Zoals in het begin van dit inleidende hoofdstuk werd opgemerkt, is de ROABeroepenclassificatie ontwikkeld vanuit de noodzaak om tot een betere beroepenindeling te komen. Het was vanuit dit oogpunt niet wenselijk te wachten op de resultaten van de (uitvoering van de) plannen van het CBS om de huidige CBS-classificatie te vernieuwen (zie Bakker e.a., 1989). We hopen dat het CBS bij de totstandkoming van een nieuwe beroepenindeling eveneens gebruik zal maken van het in onze studie centraal gestelde

3. De Kiewit en Teulings (1990) gaan daarnaast ook uit van een segregatie van mannen- en vrouwenberoepen. 
$-3-$

indelingscriterium, in casu de opleidingsachtergrond van de beroepsbeoefenaren ${ }^{4}$. Bij een nieuwe CBS-Beroepenclassificatie zal ook moeten worden geprobeerd de beroepen op anderssoortige wijze te aggregeren tot beroepsgroepen dan thans het geval is. Ook hierbij is het wenselijk te komen tot arbeidsmarktrelevante samenvoegingen.

De verdere opzet van deze studie is als volgt. Eerst zal in hoofdstuk 2 uitvoeriger worden ingegaan op de aan de ROA-Beroepenclassificatie ten grondslag liggende methodiek, waarna in hetzelfde hoofdstuk de classificatie wordt gepresenteerd. Vervolgens wordt de ROA-classificatie in hoofdstuk 3 op een aantal punten vergeleken met de huidige CBS-classificatie (waaronder de omvang en samenstelling, alsmede de sexesegregatie, opleidingen- en branchespreiding van de beroepsklassen). Tenslotte worden in hoofdstuk 4 enkele concluderende opmerkingen gemaakt.

4. Ook in de recent tot stand gekomen nieuwe beroepenclassificatie in Groot-Brittanië speelt het opleidingsprofiel van de beroepsbeoefenaren een belangrijke rol (zie Thomas en Elias, 1989). 



\section{OPZET ROA-BEROEPENCLASSIFICATIE}

\subsection{Methodiek ROA-Beroepenclassificatie}

Het doel van het hergroeperen van de beroepsgroepen van het CBS was, zoals gezegd, te komen tot beroepsklassen, die een beter inzicht geven in de in de praktijk bestaande segmenten op de arbeidsmarkt. Bij deze arbeidsmarkttheoretische benadering wordt dus met name aandacht geschonken aan het verbeteren van de afbakening tussen beroepscategorieën. Door deze "afschotting" tussen bepaalde beroepscategorieën ontstaan er (beroeps)deelmarkten op de arbeidsmarkt. Een van de belangrijkste kenmerken van een gesegmenteerde arbeidsmarkt is, dat er binnen een bepaald segment (deelmarkt) veel substitutiemogelijkheden zijn, maar tussen de segmenten juist weinig. Beroepen die een vergelijkbaar aanbod aantrekken, kunnen blijkbaar tot dezelfde deelmarkt gerekend worden en dus worden samengevoegd tot één beroepscategorie (zie ook De Kiewit en Teulings, 1990).

De segmentering van de vraagzijde heeft betrekking op beroepen; bij de aanbodzijde gaat het hierbij om de, voor de betreffende beroepen gevraagde, kwalificaties. Het genoten onderwijs vormt een zeer belangrijke indicator voor het niveau en de richting van de kwalificaties die iemand bezit. Het uitgangspunt voor de hergroepering van de CBS-beroepsgroepen wordt dan ook gevormd door de opleidingsprofielen van de onderscheiden beroepsgroepen. De achterliggende gedachte is derhalve, dat de beroepsgroepen met dezelfde onderwijsprofielen tot eenzelfde arbeidsmarktsegment behoren ${ }^{5}$.

Hierbij dient men in het oog te houden, dat bij de arbeidsmarkttheoretische benadering niet wordt uitgegaan van de benodigde (onderwijs)kwalificaties, welke het uitgangspunt zijn bij de beroepenkundige benadering, maar van de vereiste opleidingskwalificaties die de beroepsbeoefenaren binnen een bepaalde beroepsgroep hebben genoten. Met andere woorden, de opleidingsprofielen van de CBS-beroepsgroepen zijn bepaald aan de hand van de feitelijke opleidingskwalificaties (zie ook De Kiewit en Teulings, 1990).

De basis van onze hergroepering van CBS-beroepsklassen is een zogenaamde clusteranalyse. Daarbij is uitgegaan van de minimale variantie methode van Ward. Beroepsgroepen worden daarbij zodanig samengevoegd in clusters dat de variantie binnen een cluster minimaal en de variantie tussen de clusters maximaal is. Alle beroepsgroepen worden daarbij aan één cluster

5. Hoewel factoren als sexe, ras en leeftijd ook van invloed zijn op de segmentering van de arbeidsmarkt, blijven deze factoren bij het samenvoegen van beroepsgroepen buiten beschouwing. 
toebedeeld (zie De Grip, Groot en Heijke, 1987 en 1991).

De clusteranalyse is uitgevoerd op basis van de gegevens uit de Arbeidskrachtentelling (AKT) uit 1985'. De AKT is een enquête, welke van 1977 tot en met 1985 iedere twee jaar door het CBS onder een steekproef uit de gehele Nederlandse bevolking is gehouden. Ten behoeve van de clusteranalyse is gebruik gemaakt van een matrix van de werkzame beroepsbevolking naar beroepsgroep en opleidingstype op basis van de gegevens uit de AKT 1985. Zowel de variabele beroep als opleiding betrof het 3-cijferige aggregatieniveau. De variabele opleiding is gebaseerd op de Standaard Onderwijs Indeling (SOI) van het CBS, waarbij de eerste digit verwijst naar het opleidingsniveau en de tweede en derde naar de opleidingsrichting.

In tegenstelling tot de clusteranalyse bij De Kiewit en Teulings (1990) is de bestaande indeling in beroepssectoren bij de clustering niet als randvoorwaarde gehanteerd, zodat de berekende beroepsclusters niet direct geaggregeerd kunnen worden tot de huidige beroepssectoren die het CBS hanteert. Daar de CBS-beroepsgroepen de basis vormen van de beroepenclustering is er echter wel een koppeling mogelijk tussen de nieuwe beroepenclusters en de CBSberoepsgroepen ${ }^{7}$.

Op basis van de tweede en derde digit van de SOI-opleidingsvariabele zijn de circa 320 CBSberoepsgroepen eerst op basis van de vakrichting van de beroepsbeoefenaar geclusterd. Vervolgens is op basis van de eerste digit van de SOI een verdere opsplitsing gemaakt ${ }^{8}$, op grond waarvan het gemiddelde opleidingsniveau van een CBS-beroepsgroep is bepaald. Kortom de beroepsgroepen zijn eerst naar richting geclusterd en de aldus onstane beroepenclusters daarna naar niveau ${ }^{9}$ Bij de opleidingsindeling is uitgegaan van de volgende veertien vakrichtingen en vijf opleidingsniveaus:

6. Hoewel de AKT inmiddels is opgevolgd door de Enquête Beroepsbevolking (EBB) kon voor de clusteranalyse geen gebruik worden gemaakt van de EBB, aangezien in de publicaties over de EBB de variabele opleiding nog niet is opgenomen.

7. Zie bijlage 2, waarin voor alle ROA-beroepsklassen staat aangegeven welke CBSberoepsgroepen daartoe behoren.

8. De waarden 8 en 9 van de eerste digit van de SOI die betrekking hebben op opleidingen, die respectievelijk niet naar niveau zijn in te delen of waarvan het niveau onbekend is, zijn hierbij buiten beschouwing gelaten.

9. In de huidige beroepenclassificatie van het CBS worden de beroepen in tegenstelling tot de uitgevoerde clusteranalyse juist eerst op basis van niveau, c.q. complexiteit van taken ingedeeld en daarbinnen verder opgesplitst naar taakinhoud. 


\section{RICHTINGEN:}

- algemeen vormend onderwijs;

- pedagogisch onderwijs;

- theologisch onderwijs;

- agrarisch onderwijs;

- technisch onderwijs;

- transport-, communicatie- en verkeersonderwijs;

- labaratoriumonderwijs;

- medisch en paramedisch onderwijs;

- economisch-administratief en commercieel onderwijs;

- juridisch onderwijs;

- sociaal-cultureel onderwijs;

- onderwijs in de huishoudelijke verzorging;

- kunstonderwijs;

- onderwijs in de openbare orde en veiligheid.

\section{NIVEAUS:}

- basisonderwijs of lager;

- lager beroepsonderwijs, MAVO, onderbouw HAVO/VWO;

- middelbaar beroepsonderwijs, bovenbouw HAVO/VWO;

- hoger beroepsonderwijs;

- wetenschappelijk onderwijs.

Het resultaat van deze clusteranalyse, die uitgebreid wordt beschreven in De Grip, Groot en Heijke (1987 en 1991), is dat beroepsgroepen met bepaalde onderwijsprofielen qua richting en niveau bij elkaar in één cluster terecht komen. Hierbij kan een drietal kanttekeningen worden geplaatst.

In de eerste plaats bepaalt de detaillering van de opleidings- en beroepsvariabelen hoeveel beroepenclusters er kunnen worden onderscheiden. Helaas speelt daarbij het probleem dat de opleidingen door de nogal globale opleidingsvariabele (SOI 3-digit) niet verder konden worden gedifferentieerd. Dit is vooral nadelig voor de technische beroepen daar deze juist op een zeer laag aggregatieniveau ingedeeld zijn. Voor een nadere indeling van met name de technische beroepen is dan ook dankbaar gebruik gemaakt van een soortgelijke clusteranalyse die $\mathrm{De}$ Kiewit en Teulings (1990) recentelijk hebben uitgevoerd op basis van de (helaas enigszins gedateerde) AKT 1979. Daarbij hadden zij namelijk de beschikking over een gedetailleerdere opleidingsvariabele (SOI 5-digit). Met gebruikmaking van hun resultaten kunnen met name 
binnen de technische sector een aantal nader gespecificeerde beroepsdeelmarkten worden onderscheiden.

In de tweede plaats moet geconstateerd worden, dat de clusteranalyse met name geschikt is voor het onderscheiden van zogenaamde beroepsdeelmarkten, waarbij een bepaalde opleiding specifiek opleidt voor een bepaald beroep en dit beroep nagenoeg alleen met die opleiding uitgeoefend kan worden ${ }^{10}$. Beroepsgroepen die, bijvoorbeeld op grond van de zeer diverse of algemene opleidingsachtergronden van de beroepsbeoefenaren, niet onderscheiden kunnen worden van andere beroepsgroepen met een eveneens heterogene of algemene opleidingsstructuur, zullen derhalve in één beroepencluster samenkomen. Bij de clusteranalyse blijken inderdaad beroepsgroepen die in belangrijke mate bestaan uit werkzame personen met basisonderwijs of algemeen voortgezet onderwijs als hoogst genoten onderwijs op grond van de clustercriteria niet verder te onderscheiden, terwijl deze beroepsgroepen qua werkzaamheden soms ver uiteen liggen. Om deze beroepsclusters toch verder te kunnen onderscheiden zijn de volgende aanvullende arbeidsmarkttheoretische en beroepenkundige criteria gebruikt, waarbij het streven naar homogeniteit binnen en heterogeniteit tussen de beroepsclusters steeds als leidraad heeft gediend:

- dominantie van bepaalde (specifieke) opleidingsrichtingen of niveaus; hoewel een CBSberoepsgroep in het algemeen als onderwijsprofiel "basisonderwijs of lager" kan hebben, is het mogelijk, dat daarnaast een belangrijk deel van de beroepsbeoefenaren een opleiding heeft gevolgd, die (specifiek) is gericht op het betreffende beroep;

- het niveau, de richting en de specifieke aspecten van de benodigde bekwaamheden; ofschoon dit soms niet op het eerste gezicht blijkt uit het onderwijsprofiel van de beroepsbeoefenaren, zijn voor het vervullen van bepaalde beroepen wel bepaalde bekwaamheden en specifieke vaardigheden nodig, welke niet altijd tot uiting komen in het opleidingsprofiel;

- $\quad$ aard van de werkzaamheden; hierbij kan men denken aan verschillen tussen beroepen met betrekking tot tegenstellingen zoals hoofd- versus hand-arbeid, binnen- versus buitenarbeid en uitvoerende versus leidinggevende werkzaamheden ${ }^{11}$;

- $\quad$ soort arbeidsterrein; dit criterium heeft betrekking op de plaats, waar de werkzaamheden worden uitgeoefend, zoals het kantoor, de winkel, de werkplaats, de fabriek, het ziekenhuis e.d.; het arbeidsterrein, dat enige verwantschap vertoond met de sector waarin de beroepsbeoefenaren werkzaam zijn, wordt ook wel aangeduid als het 'werkveld'.

10. Voor zover althans de opleidings- en beroepsvariabele hiervoor gedetailleerd genoeg zijn onderscheiden.

11. Zie hiervoor ook de typologie van Holland (Spijkerman, 1989). 
Ten aanzien van de celvulling zijn bovendien de volgende randvoorwaarden gehanteerd:

- de cellen moeten voldoende waarnemingen opleveren in verband met de privacygevoeligheid en de statistische betrouwbaarheid; dit betekent een minimale grootte van circa 2.500 werkzame personen per beroepscluster;

- met het oog op het evenwicht tussen de cellen zal een maximale grootte van circa 400.000 werkzame personen per beroepscluster aangehouden moeten worden ${ }^{12}$;

- $\quad$ in aansluiting op het uitgangspunt van minimale variantie tussen de beroepsclusters bij de clusteranalyse, dient er naar gestreefd te worden een beroepscluster ook getalsmatig zo evenwichtig mogelijk samen te stellen uit de CBS-beroepsgroepen.

De derde kanttekening betreft de heterogeniteit van de CBS-beroepsgroepen, die als basis fungeerden voor de clusteranalyse. Deze heterogeniteit vormt een groot probleem bij het hergroeperen van de beroepsgroepen tot homogene beroepsclusters. In een aantal gevallen zijn in de beroepenclassificatie van het CBS namelijk beroepen samengevoegd in éen beroepsgroep, die zowel qua opleidingsprofiel als een aantal andere beroepskenmerken zeer ver uiteen liggen. Dit geldt met name voor de zogenaamde 'restgroepen', waarin een divers scala van vaak jonge beroepen, die inmiddels een belangrijk aandeel kunnen hebben in de beroepenstructuur, zijn ondergebracht. Op deze plaats willen we enkele in het oog springende voorbeelden noemen. Zo zijn de beroepsgroepen 079 (overige medische, paramedische en verwante functies), 199 (overige wetenschappelijke e.a. vakspecialisten) en 649 (oester-, mosselkwekers, vissers en jagers n.e.g.) zeer heterogeen samengesteld; respectievelijk van EEG-laborant of pedicure tot hoofdinspecteur voor de volksgezondheid; van levensverzekeraar tot waarzegger en van visser (n.e.g.) tot jachtopziener. Indien de laag geaggregeerde beroepsgroepen ${ }^{13}$ al (te) heterogeen van aard zijn, is het dus onmogelijk om op een hoger aggregatieniveau hiervan homogene clusters samen te stellen ${ }^{14}$.

12. Dit is gebaseerd op het criterium dat het CBS noemt in haar notitie "Een aanzet voor een nieuwe beroepenclassificatie" (Bakker e.a.), waarin wordt gesteld, dat een beroepscategorie niet meer dan 5 à 10 maal het gemiddeld aantal beroepsbeoefenaren mag tellen.

13. In een aantal gevallen bestaan zelfs de beroepen (op 4 digit) uit een te heterogeen spectrum van functies. Dit geldt bijvoorbeeld voor het beroep met de code 1999 loverige vakspecialisten), waarin zowel waarzeggers, voorlichters, impresario's en lectoren zijn samengevoegd.

14. Tenzij deze heterogene beroepsgroepen op een hoger aggregatieniveau op basis van een gemeenschappelijk kenmerk kunnen worden samengevoegd. Op alle onderscheiden aggregatieniveaus (digits) dient de mate van detaillering voor alle onderscheiden beroepscategorieën derhalve gelijk te zijn. 


\subsection{Structuur ROA-Beroepenclassificatie}

Aan de hand van bovengenoemde clusteranalyse en aanvullende criteria is een indeling ontstaan in 93 beroepsklassen. Deze indeling kan worden opgevat als een alternatief voor de huidige indeling van het CBS in 82 beroepsklassen. Enerzijds zijn deze alternatieve ROA-beroepsklassen homogener naar opleidingsachtergrond van de beroepsbeoefenaren, zodat zij meer in overeenstemming zijn met de op de arbeidsmarkt waar te nemen (beroeps)deelmarkten. Anderzijds is de mate van detaillering meer in evenwicht gebracht. Bij de ROA-beroepsklassen zijn vooral de technische beroepsklassen meer samengevoegd en de beroepsklassen in de andere beroepssectoren, zoals die door het CBS worden onderscheiden, daarentegen juist verder opgesplitst. Aangezien het niet altijd mogelijk of zinvol is gegevens met betrekking tot beroepenclusters op dit lage aggregatieniveau te onderzoeken of te publiceren, heeft het ROA in deze beroepsklassen een verdere structuur aangebracht.

Deze 93 beroepsklassen zijn op een hiërarchische wijze gestructureerd. Dat wil zeggen, dat de hieruit resulterende beroepenclassificatie ${ }^{15}$ op verschillende niveaus kan worden gehanteerd. Uiteraard zijn daaraan een aantal (statistische) voorwaarden verbonden.

Een eerste voorwaarde voor statistische toepassing is dat de beroepenclassificatie op ieder aggregatieniveau een specifieke betekenis heeft. Op ieder aggregatieniveau dient de beroepenclassificatie dus bruikbaar en betekenisvol te zijn. Een tweede randvoorwaarde betreft de mate van detaillering op de hogere aggregatieniveaus. Op ieder niveau moeten de onderscheiden beroepscategorieën min of meer dezelfde mate van detaillering kennen (zie ook Bakker e.a., 1989).

Om aan deze voorwaarden te voldoen is aan alle door het ROA onderscheiden beroepsklassen een vier-cijferige code (anders gezegd: 4 digits) toegekend. Aan iedere digit is een bepaald criterium verbonden. $\mathrm{Er}$ is een aantal redenen voor het feit, dat het ROA haar beroepsklassen een vier-cijferige, in plaats van een twee digit code geeft, zoals bij de beroepenclassificatie van het CBS is gebeurd. Voor analyse- en publicatiedoeleinden blijken de tien door ons onderscheiden beroepssectoren te grof van karakter, terwijl het niveau van beroepsklasse vaak problemen oplevert ten aanzien van de celontwikkeling bij kruisverbanden met andere variabelen. Daarom zijn er bij de beroepenclassificatie van het ROA twee analyseniveaus toegevoegd tussen die van de beroepssectoren en -klassen.

15. Zie bijlage 1 voor een weergave van de gehele beroepenclassificatie. 
Evenals bij het CBS onderscheidt het ROA op het eerste digitniveau een tiental beroepssectoren. De ROA-beroepenindeling is daarbij gebaseerd op de hoofdindeling van de Standaard Onderwijs Indeling (SOI) van het $\mathrm{CBS}^{16}$. Bij het toekennen van de waarde van de eerste digit is het onderwijsprofiel van de betreffende beroepsklasse de doorslaggevende factor geweest ${ }^{17}$. Het gaat om de volgende tien beroepssectoren:

0 pedagogische beroepen

1 culturele beroepen

2 agrarische beroepen

3 technische, ambachts- en industrieberoepen

4 transportberoepen

5 medische en paramedische beroepen

6 economisch-administratieve beroepen

7 sociaal-culturele beroepen

8 verzorgende en dienstverlenende beroepen

9 openbare orde- en veiligheidsberoepen

Op het tweede digitniveau worden de 10 beroepssectoren verbijzonderd in 27 beroepstakken $^{18}$, welke verwijzen naar de branche, c.q. het arbeidsterrein, waarin de betreffende beroepsbeoefenaren werkzaam zijn. Men zou kunnen stellen dat het eerste en tweede digitniveau samen betrekking hebben op de vakrichting van de beroepsbeoefenaren ${ }^{19}$. De volgende beroepstakken worden daarbij onderscheiden:

16. Hierbij is op inhoudelijke gronden een uitzondering gemaakt voor de kunst- en vormgevende beroepen. In de SOI wordt het kunstonderwijs namelijk samen met het onderwijs in de persoonlijke/sociale verzorging ondergebracht in éen sector, terwijl het ROA beroepen met een dergelijk onderwijsprofiel onderbrengt bij de culturele beroepen.

17. Beroepenkundig gezien kan men wellicht aannemelijk maken, dat bijvoorbeeld een beroepsklasse als auteurs, journalisten e.d. niet tot de sociaal-culturele, maar tot de culturele beroepen behoort. Aangezien de school voor de journalistiek, welke een dominante plaats heeft in het opleidingsprofiel van deze beroepsklasse, volgens de SOI gerekend wordt tot het sociaal-culturele onderwijs, is deze beroepsklasse bij de sociaalculturele beroepen ondergebracht.

18. Voor het begrip takken is aansluiting gezocht bij de bedrijvenindeling van het CPB. Het CPB onderscheidt circa 25 bedrijfstakken. Inhoudelijk gezien zijn de codes min of meer verwant aan de Standaard Bedrijfsindeling (SBI) van het CBS.

19. Indien een bepaalde beroepssector niet is onderverdeeld in beroepstakken, of bepaalde beroepssegmenten of beroepsklassen niet tot een specifieke beroepstak behoren, wordt op het $2 \mathrm{e}$ digitniveau de waarde 0 aan de code toegekend. 
0

PEDAGOGISCHE BEROEPEN

01 onderwijs(kundige) beroepen

02 sport(instructieve) beroepen

1

CULTURELE BEROEPEN

11 taal- en letterkundige beroepen

12 theologische beroepen

13 kunst- en vormgevende beroepen

2

\section{AGRARISCHE BEROEPEN}

20 agrarische beroepen

3

TECHNISCHE, AMBACHTS- EN INDUSTRIEBEROEPEN

31 voedings- en genotmiddelenberoepen

32 textielberoepen

33 hout- en papierberoepen

34 grafische beroepen

35 chemische beroepen

36 metaalberoepen

37 electrotechnische beroepen

38 bouwmaterialen-, glas- en aardewerkberoepen

39 bouw- en installatieberoepen

4

TRANSPORTBEROEPEN

41 maritieme e.a. waterwegtransportberoepen

42 rail- en wegtransportberoepen

43 lucht- en overige transportberoepen

5

MEDISCHE EN PARAMEDISCHE BEROEPEN

50 medische en paramedische beroepen

6 ECONOMISCH-ADMINISTRATIEVE BEROEPEN

61 administratieve beroepen

62 commerciële beroepen

63 bestuurlijke beroepen

7 SOCIAAL-CULTURELE BEROEPEN

70 sociaal-culturele beroepen

8 VERZORGENDE EN DIENSTVERLENENDE BEROEPEN

81 horecaberoepen

82 verzorgende beroepen

9 OPENBARE ORDE- EN VEILIGHEIDSBEROEPEN

91 politie-, brandweer- en bewakingsberoepen

92 militaire beroepen

Op het derde digitniveau worden in totaal 48 beroepssegmenten onderscheiden, welke zijn gebaseerd op het hoogst behaalde onderwijsniveau van de beroepsbeoefenaren. Dit is op de volgende wijze bepaald. Eerst is, aan de hand van de AKT uit 1985 voor alle beroepsklassen berekend welk aandeel van de in 1985 in die klasse werkzame personen een bepaald onderwijsniveau had. Hierbij is uitgegaan van de vijf opleidingsniveaus die bij de clusteranalyse 
zijn gebruikt (zie paragraaf 2.1.). Vervolgens is voor alle onderscheiden beroepsklassen de mediaan $^{20}$ van het onderwijsniveau berekend, op grond waarvan drie beroepsniveau's zijn onderscheiden:

\author{
Beroepsniveau \\ lager beroepsniveau \\ middelbaar beroepsniveau
}

hoger beroepsniveau

\section{Mediaan}

basisonderwijs of lager, MAVO, onderbouw HAVO/VWO

middelbaar beroepsonderwijs, bovenbouw HAVO/VWO hoger beroepsonderwijs, wetenschappelijk onderwijs

Op dit derde digitniveau worden in feite de deelmarkten onderscheiden, zoals deze zich in de praktijk op de arbeidsmarkt voordoen. Bij de segmentatie van de arbeidsmarkt speelt immers niet alleen de gevraagde vakrichting, waarnaar de eerste twee digits van de beroepenclassificatie verwijzen, maar zeker ook het gevraagde opleidingsniveau een rol. Vandaar dat hier gesproken wordt van beroepssegmenten.

Deze indeling naar mediaan onderwijsniveau is zowel op de beroepssectoren, als op de beroepstakken van toepassing, zodat het eveneens mogelijk is een analyseniveau te creëren, waarbij alleen de eerste en derde digit zijn betrokken. Op deze wijze ontstaan er 21 clusters van beroepsklassen. Hierdoor ontstaat de keuzemogelijkheid de beroepstakkendimensie al dan niet in de analyse betrekken.

Aangezien in veel gevallen meer dan éen beroepsklasse tot hetzelfde beroepssegment behoort, zijn deze beroepssegmenten op het vierde digit-niveau verder opgesplitst. Hoewel de vierde digit slechts een volgnummer betreft, is hierbij evenwel geprobeerd de betreffende beroepsklassen op inhoudelijke gronden in een zo logisch mogelijke volgorde te plaatsen. Daarbij is bijvoorbeeld gekeken of een beroepsklasse betrekking heeft op de winning van grondstoffen, dan wel op de produktie van respectievelijk halffabrikaten en eindprodukten.

De beroepenclusters zijn, omwille van de leesbaarheid op alle vier de niveaus, voor zover dat mogelijk is, zo bondig mogelijk omschreven. Dit heeft als consequentie, dat in omvang kleine

20. Er is uitgegaan van de mediaan, omdat deze een betere indicatie geeft van het genoten onderwijs, dan de modus of het gemiddelde onderwijsniveau. Het gemiddelde is namelijk te gevoelig voor uitschieters en het hanteren van de modus is een slechte maat, indien meerdere onderwijsniveaus in een bepaalde beroepsklasse van belang zijn. 
$-13-$

beroepscategorieën af en toe niet in de omschrijving zijn opgenomen. In ieder geval is er in bijlage 2 een zogenaamd koppelschema opgenomen, waarin voor alle door het ROA onderscheiden beroepsklassen staat aangegeven welke CBS-beroepsgroepen daaronder ressorteren. 


\section{IMPLICATIES ROA-BEROEPENCLASSIFICATIE VOOR HET INFORMATIE- SYSTEEM ONDERWIJS-ARBEIDSMARKT}

\subsection{Inleiding}

In dit hoofdstuk zal nader worden ingegaan op de bruikbaarheid van de nieuwe ROABeroepenclassificatie voor kwantitatieve analyses. Daarbij zal ook worden ingegaan op de implicaties van de nieuwe indeling voor het informatiesysteem onderwijs-arbeidsmarkt, zoals dat door het ROA wordt ontwikkeld. We willen hierbij nagaan of de ROA-beroepsklassen een beter inzicht geven in de arbeidsmarktsegmentatie dan de huidige CBS-beroepsklassen. Enerzijds zullen derhalve de omvang en de samenstelling van de beroepsklassen worden vergeleken. Anderzijds zullen de indices voor de sexe-specifieke beroepssegregatie, evenals de opleidingenen branchespreiding, voor beide beroepklassenindelingen worden berekend.

\subsection{Omvang en samenstelling ROA-beroepsklassen}

Bij de omvang van de beroepsklassen (naar het aantal werkenden) gaat het erom, dat deze aan de ene kant voldoende groot zijn in verband met steekproefvoorwaarden, terwijl aan de andere kant de onderscheiden beroepsklassen ten behoeve van de analyse en presentatie wel voldoende gedetailleerd moeten zijn. In bijlage 3 wordt een overzicht gegeven van het aantal werkzame personen in 1985 volgens de Arbeidskrachtentelling (AKT) voor respectievelijk de CBS- en de ROA-beroepsklassen. In totaal zijn er in 1985 5.086.000 werkenden, waarvan 34\% uit vrouwen bestaat. Het gemiddelde aantal werkenden per beroepsklasse is in de ROA-indeling vanzelfsprekend lager, omdat deze indeling meer klassen onderscheidt. De variantie is in de ROA-indeling echter ook lager, hetgeen tot uiting komt in de kleinere spreiding van de ROAberoepsklassen over de onderscheiden grootteklassen (zie tabel 3.1.).

Tabel 3.1. Procentuele verdeling van de CBS- en ROA-beroepsklassen naar grootteklasse van werkzame personen volgens Arbeidskrachtentelling 1985

\begin{tabular}{rcc}
\hline Aantal werkzame personen & $\begin{array}{c}\text { CBS-indeling } \\
\%\end{array}$ & $\begin{array}{c}\text { ROA-indeling } \\
\%\end{array}$ \\
\hline$\leq 5.000$ & 13 & 5 \\
$5.001-10.000$ & 10 & 6 \\
$10.001-25.000$ & 26 & 33 \\
$25.001-100.000$ & 26 & 38 \\
$>100.000$ & 25 & 18 \\
\hline
\end{tabular}

Bron: CBS/ROA 
Terwijl van de CBS-beroepsklassen slechts de helft 10.001 tot 100.000 werkzame personen bevat, behoort van de ROA-beroepsklassen bijna driekwart tot deze middelgrote klassen. De ROA-beroepsklassen zijn daarentegen juist ondervertegenwoordigd in de kleinste en grootste klassen. Stellen we bijvoorbeeld de ondergrens op 5000 werkzame pesonen (zoals het CBS in haar publicaties over de Enquête Beroepsbevolking hanteert) dan behoort bij de ROA-indeling slechts $5 \%$ van de beroepsklassen hiertoe tegenover $13 \%$ van de CBS-beroepsklassen. Ook het aandeel zeer omvangrijke beroepsklassen is bij de ROA-beroepenclassificaties lager: het percentage beroepsklassen dat 100.000 werkenden of meer bevat, is bij de ROA-indeling $18 \%$, tegenover $25 \%$ bij de CBS-indeling. Gemeten naar de omvang van de beroepsklassen is de ROA-indeling dus homogener dan de CBS-beroepsklassenindeling.

Voor vier CBS-beroepsklassen zullen we nader ingaan op de implicaties van het gebruik van de ROA-beroepenindeling. Het betreft de volgende 'dienstverlenende' CBS-beroepsklassen, die in het verleden bij de ontwikkeling van het informatiesysteem onderwijs-arbeidsmarkt aanleiding hebben gegeven tot problemen, aangezien zij niet alleen erg groot (naar grootte de $1^{\mathrm{e}}, 3^{\mathrm{e}}, 4^{\mathrm{e}}$ en $18^{\mathrm{e}}$ beroepsklasse), maar vooral bijzonder heterogeen zijn. Het gaat om de CBS-beroepsklassen:

06/07 genees- en verpleegkundigen e.d.;

13 leerkrachten;

19 sociaal-wetenschappelijke e.a. vakspecialisten;

39 diverse administratieve functies n.e.g. (niet eerder genoemd).

Bij de bespreking gaan we uit van de CBS-beroepsklassen, welke zijn opgebouwd uit beroepsgroepen. Teneinde onduidelijkheid over het begrip beroepsklasse te voorkomen zullen we steeds expliciet aangeven of het de CBS- of de ROA-beroepsklassen betreft. Bij de beroepsgroepen ontstaat een dergelijke verwarring niet: hier gaat het altijd om de CBS-beroepsgroepen. Achtereenvolgens zullen we voor de vier bovengenoemde CBS-beroepsklassen en de corresponderende ROA-beroepsklassen het aantal werkzame personen, de verdeling naar geslacht en opleidingsniveau evenals de implicaties voor het informatiesysteem onderwijsarbeidsmarkt aangeven.

Genees- en verpleegkundigen e.d. (CBS-code 06/07)

In de CBS-indeling is dit één van de grootste beroepsklassen: 266.700 werkenden, onder te verdelen in 75.000 (28\%) mannen en 191.700 (72\%) vrouwen. De onderliggende beroepsgroepen omvatten zowel universitair opgeleide artsen en specialisten (veelal mannen), als (met name vrouwelijk) verplegend personeel en (paramedische) therapeuten met een 
middelbare of hogere beroepsopleiding. In de ROA-indeling worden de vijftien beroepsgroepen die tot de bovengenoemde CBS-beroepsklasse behoren ingedeeld in 9 nieuwe ROAberoepsklassen:

- gediplomeerde verpleegkundigen, verloskundigen (ROA-code 5021);

- leerling-verpleegkundigen, zieken- en kraamverzorgenden (ROA-code 5022);

- apothekersassistenten, opticiens, orthoptisten (ROA-code 5024);

- EEG-laboranten, keurmeesters, diëtisten, logopedisten, pedicuren e.d. (ROA-code 5025);

- fysio-, arbeids- e.a. bewegingstherapeuten (ROA-code 5031);

- radiologische, medische en biologische laboranten (ROA-code 5032);

- geneeskundigen, medische adviseurs, apothekers (ROA-code 5033);

- diergeneeskundigen, veterinaire geneeskundigen (ROA-code 5034);

- tandheelkundigen en tandheelkundige specialisten (ROA-code 5035).

Tabel 3.2. Aantal werkzame personen in 1985 naar CBS en ROA-beroepsklassen en geslacht.

\begin{tabular}{|c|c|c|c|c|}
\hline & CBS-groepen & mannen & vrouwen & totaal \\
\hline \multicolumn{5}{|c|}{ CBS-klasse } \\
\hline $06 / 07$ & 061-079 & 75.000 & 191.700 & 266.700 \\
\hline \multicolumn{5}{|c|}{ ROA-klasse ${ }^{21}$} \\
\hline 5021 & $071+073$ & 17.900 & 65.400 & 83.300 \\
\hline 5022 & $072+074$ & 12.300 & 74.000 & 86.300 \\
\hline 5024 & $068+075$ & 2.300 & 10.200 & 12.500 \\
\hline 5025 & $064+069+079$ & 6.100 & 14.800 & 20.900 \\
\hline 5031 & 076 & 9.500 & 15.700 & 25.200 \\
\hline 5032 & $054+077$ & 10.600 & 15.300 & 25.900 \\
\hline 5033 & $061+067$ & 19.700 & 6.200 & 26.000 \\
\hline 5034 & 065 & 2.000 & 240 & 2.200 \\
\hline 5035 & 063 & 3.900 & 880 & 4.800 \\
\hline
\end{tabular}

Bron: $\mathrm{CBS} / \mathrm{ROA}$

Zoals uit tabel 3.2. blijkt, variëren de aantallen werkenden in deze ROA-beroepsklassen van 2.200 (5034, diergeneeskundigen) tot 86.300 (5022, leerling-verpleegkundigen, zieken- en kraam verzorgenden). Door het splitsen van deze grote en heterogene CBS-beroepsklasse komt eveneens de segregatie tussen specifieke mannen- en vrouwenberoepen in de gezondheidszorg beter tot uiting. Terwijl bij de (leerling-)verpleegkundigen het merendeel van de werkenden uit

21. In de ROA-indeling wordt onder code 5032 overigens ook de CBS-beroepsgroep 054 (botanische, medische e.d. analisten en landbouwkundige assistenten) opgenomen. 
vrouwen bestaat (namelijk $82 \%$ ), blijken bij de ROA-beroepsklassen van artsen en medisch specialisten mannen sterk oververtegenwoordigd (namelijk 78\%).

Tabel 3.3. Procentuele verdeling van de werkzame personen in 1985 naar opleidingsniveau (SOI 1e digit) en CBS- en ROA-beroepsklassen

\begin{tabular}{|c|c|c|c|c|c|}
\hline & BASISONDERWIJS & AVO-LT/LBO & AVO-HT/MBO & $\mathrm{HBO}$ & wo \\
\hline CBS-klasse & $\%$ & $\%$ & $\%$ & $\%$ & $\%$ \\
\hline 06/07 & 1 & 6 & 59 & 21 & 12 \\
\hline \multicolumn{6}{|l|}{ ROA-klasse } \\
\hline 5021 & 0 & 0 & 75 & 25 & 0 \\
\hline 5022 & 2 & 14 & 78 & 6 & 0 \\
\hline 5023 & 4 & 15 & 71 & 8 & 2 \\
\hline 5024 & 1 & 3 & 95 & 1 & 0 \\
\hline 5025 & 1 & 15 & 43 & 38 & 3 \\
\hline 5031 & 1 & 3 & 27 & 69 & 1 \\
\hline 5032 & 1 & 6 & 29 & 62 & 2 \\
\hline 5033 & 0 & 0 & 1 & 2 & 97 \\
\hline 5034 & 0 & 0 & 0 & 0 & 100 \\
\hline 5035 & 0 & 0 & 0 & 1 & 99 \\
\hline
\end{tabular}

Bron: $\mathrm{CBS} / \mathrm{ROA}$

In de ROA-beroepenindeling wordt, in tegenstelling tot de CBS-Beroepenclassificatie, expliciet onderscheid gemaakt naar het mediane opleidingsniveau. Hierbij hebben de 502-codes betrekking op beroepsklassen op middelbaar niveau en de 503-codes op hoger opgeleiden. Hierdoor is het nu mogelijk beroepsklassen met beroepsbeoefenaren met een universitaire opleiding van beroepsklassen met (merendeels) werkenden met een middelbaar opleidingsprofiel te onderscheiden (zie tabel 3.3. en bijlage 4). Zo bestaan bijvoorbeeld de beroepsklassen 5033 (geneeskundigen, apothekers), 5034 (dierenartsen, veterinair deskundigen) en 5035 (tandartsen) nagenoeg volledig uit werkenden met een academische achtergrond, terwijl in de ROAberoepsklasse van apothekersassistenten en opticiens bijna iedereen een middelbare opleidingsachtergrond heeft.

Voor het genereren van arbeidsmarktinformatie, zoals bijvoorbeeld voor het studie- en beroepskeuzesysteem I-See!, is het erg belangrijk dat er een onderscheid gemaakt kan worden tussen de beroepen, die tot verschillende arbeidsmarktsegmenten behoren. In de ROA-indeling wordt hiertoe bij de (para)medische beroepen een belangrijke stap in de goede richting gezet. 
Leerkrachten (CBS-code 13)

Tabel 3.4. Aantal werkzame personen in 1985 naar CBS en ROA-beroepsklassen en geslacht

\begin{tabular}{|c|c|c|c|c|}
\hline & CBS-groepen & mannen & vrouwen & totaal \\
\hline \multicolumn{5}{|c|}{ CBS-klasse } \\
\hline 13 & $131-139$ & 152.500 & 122.600 & 275.100 \\
\hline \multicolumn{5}{|c|}{ ROA-klasse } \\
\hline $\begin{array}{l}0131 \\
0132 \\
0133\end{array}$ & $\begin{array}{r}133-135 \\
131-132 \\
139\end{array}$ & $\begin{array}{l}37.900 \\
93.200 \\
21.400\end{array}$ & $\begin{array}{r}63.700 \\
51.600 \\
7.200\end{array}$ & $\begin{array}{r}101.600 \\
144.800 \\
28.600\end{array}$ \\
\hline
\end{tabular}

Bron: CBS/ROA

In de CBS-indeling wordt deze beroepsklasse onderverdeeld in 5 beroepsgroepen: leerkrachten aan scholen (voor voorgezet en hoger onderwijs); onderwijzers basisonderwijs, onderwijzers buitengewoon onderwijs en kleuteronderwijzers en als laatste de beroepsgroep van directeuren en hoofden van scholen en andere (niet eerder genoemde) onderwijskundige functies. In totaal gaat het om 275.000 werkzame personen in 1985 , waaronder $45 \%$ vrouwen.

In de ROA-indeling worden de onderwijzers in het basisonderwijs en het (voormalige) kleuteronderwijs, evenals het speciaal onderwijs ondergebracht in één beroepsklasse (ROA-code 0131). De leerkrachten voortgezet en hoger onderwijs vormen één beroepsklasse (ROA-code 0132) en de schoolhoofden en andere onderwijskundige functies zijn eveneens in een aparte categorie (ROA-code 0133) ondergebracht. De aantallen werkzame personen in 1985 zijn, ingedeeld naar ROA-beroepsklassen, voor de leerkrachten in het basisonderwijs $102.000163 \%$ vrouwen), voor de docenten in het voortgezet en hoger onderwijs 145.000 (36\% vrouwen) en voor de schoolhoofden en andere onderwijskundige beroepen 28.600 (25\% vrouwen). Op deze wijze wordt een omvangrijke beroepsklasse, waarbij duidelijk sprake is van verschillende arbeidsmarktsegmenten voor de onderliggende beroepsgroepen, in enigszins meer afgebakende beroepsklassen omgezet. Doordat deze CBS-klasse verder is onderverdeeld, komt nu naar voren dat vrouwen als leerkrachten vaker in het basis-, dan in het voortgezet en hoger onderwijs werkzaam zijn en dat zij zijn ondervertegenwoordigd in beroepen als schoolhoofd e.d. 
Tabel 3.5. Procentuele verdeling van de werkzame personen in 1985 naar opleidingsniveau (SOI 1e digit) en CBS- en ROA-beroepsklassen

\begin{tabular}{lccccc}
\hline & BASISONDERWIJS & AVO-LT/LBO & AVO-HT/MBO & HBO & WO \\
\hline CBS-klasse & & & & & \\
13 & 0 & 1 & 9 & 71 & 19 \\
ROA-klasse & & & & & \\
0131 & 0 & 0 & 12 & 87 & 1 \\
0132 & 0 & 1 & 5 & 63 & 30 \\
0133 & 0 & 4 & 19 & 51 & 25 \\
\hline
\end{tabular}

Bron: CBS/ROA

Arbeidsmarktsegmentatie blijkt ook als men in tabel 3.5. het opleidingspofiel van deze drie pedagogische beroepen bekijkt (zie ook bijlage 4). Terwijl de leerkrachten uit het basisonderwijs grotendeels een HBO-opleiding (in casu de PABO) hebben genoten ${ }^{22}$, hebben de docenten voor het voortgezet onderwijs, evenals de schoolhoofden beduidend vaker een academische opleidingsachtergrond.

Ten aanzien van het genereren en presenteren van arbeidsmarktinformatie in het algemeen en prognoses in het bijzonder is het relevant dat er onderscheid kan worden gemaakt tussen de leerkrachten voor enerzijds het basis- en anderzijds het voortgezet onderwijs, alsmede de schoolhoofden en andere onderwijskundige beroepen. Het gaat hier om duidelijk afgebakende arbeidsmarktsegmenten waarvan de werkgelegenheidsontwikkeling sterk verschillend kan zijn. De werkgelegenheid voor leerkrachten is immers sterk gebonden aan demografische ontwikkelingen die op een bepaald moment verschillende gevolgen hebben voor de werkgelegenheid in het basisonderwijs en de werkgelegenheid in het voortgezet of hoger onderwijs. Zo zal bijvoorbeeld een geboorte-afname het eerst doorwerken in de vraag naar basisonderwijzers en pas daarna een daling veroorzaken in de vraag naar leraren in het middelbaar en hoger onderwijs.

Voor het prognosticeren van de arbeidsmarktperspectieven van leerkrachten is het eveneens

22. De $12 \%$ van de werkenden met een middelbare opleiding hebben betrekking op degenen, die voor het behalen van de onderwijsbevoegdheid voor het voormalige kleuteronderwijs de KLOS hebben gevolgd, welke volgens de SOI tot het middelbare opleidingsniveau wordt gerekend. Sinds het kleuteronderwijs is samengevoegd met het basisonderwijs, is deze opleiding opgeheven en kan alleen nog een onderwijsbevoegdheid voor het gehele basisonderwijs (incl. kleuteronderwijs) aan de PABO (HBO) worden behaald. 
zinvol als een onderscheid naar de verschillende vakrichtingen zoals talen, economie en technische vakken kan worden gemaakt. De ROA-indeling is hiervoor nog te grof. Dit heeft te maken met het feit dat de ROA-indeling noodzakelijkerwijs moest worden opgebouwd uit de CBS-beroepsgroepen. Op dit niveau wordt het onderscheid naar vakrichting helaas niet gemaakt.

(Sociaal) wetenschappelijke en andere vakspecialisten (CBS-code 19)

In deze CBS-beroepsklasse werkten in 1985108.600 personen waaronder $46 \%$ vrouwen. Deze beroepsklasse wordt door het CBS onderverdeeld in de volgende zes beroepsgroepen, welke in de ROA-Beroepenclassificatie allen als een afzonderlijke beroepsklasse zijn opgenomen (tussen haakjes staat telkens de ROA-codering vermeld):

- bibliothecarissen, archivarissen e.d. (7031);

- sociologen, psychologen en andere sociale wetenschapsbeoefenaren (7034);

- maatschappelijk werkers en culturele werkers n.e.g. (7033);

- personeels-, beroepenspecialisten en -adviseurs (7032);

- taalkundigen, vertalers, tolken (1131);

- overige wetenschappelijke en andere vakspecialisten (7035).

Voor het leveren van arbeidsmarktinformatie is het van belang dat er nu binnen een oorspronkelijk heterogene beroepsklasse onderscheid kan worden gemaakt tussen een aantal beroepen met enerzijds verschillende opleidingsprofielen (met name wat betreft de gevolgde opleidingsrichting) en anderzijds sterk uiteenlopende werkzaamheden en werkkringen. Voorheen waren immers de twee grootste beroepsgroepen (in casu de maatschappelijk werkers met 48.400 en de sociale wetenschappers met 23.800 werkenden) bepalend voor de beschrijving van de arbeidsmarktsituatie van deze gehele CBS-beroepsklasse van (sociaal) wetenschappelijke en andere vakspecialisten. De andere, kleinere, beroepsgroepen binnen deze CBS-beroepsklasse 'vervuilden' aan de ene kant de arbeidsmarktinformatie over zowel de maatschappelijk werkers als de sociale wetenschapsbeoefenaren, terwijl aan de andere kant over deze kleinere beroepsgroepen geen afzonderlijke arbeidsmarktinformatie kon worden verschaft. In de ROAindeling zijn deze beroepsgroepen derhalve in afzonderlijke beroepsklassen ingedeeld. De taalkundigen e.d. zijn overigens ook in een andere beroepssector geplaatst (namelijk van de culturele beroepen) dan de andere beroepsgroepen uit CBS-klasse 19, die bij de sociaal-culturele beroepen zijn ondergebracht. 
Tabel 3.6. Aantal werkzame personen in 1985 naar CBS en ROA-beroepsklassen en geslacht

\begin{tabular}{|c|c|c|c|c|}
\hline & CBS-groepen & mannen & vrouwen & totaal \\
\hline \multicolumn{5}{|c|}{ CBS-klasse } \\
\hline 19 & $191-199$ & 58.600 & 50.000 & 108.600 \\
\hline \multicolumn{5}{|c|}{ ROA-klasse } \\
\hline 1131 & 195 & 1.400 & 2.200 & 3.600 \\
\hline 7031 & 191 & 6.200 & 6.500 & 12.700 \\
\hline 7032 & 194 & 7.700 & 3.300 & 11.000 \\
\hline 7033 & 193 & 22.000 & 26.300 & 48.400 \\
\hline 7034 & 192 & 14.400 & 9.400 & 23.800 \\
\hline 7035 & 199 & 7.000 & 2.200 & 9.200 \\
\hline
\end{tabular}

Bron: $\mathrm{CBS} / \mathrm{ROA}$

De grootte van deze ROA-beroepsklassen varieert van 3.600 voor de taalkundigen e.d. tot 48.400 voor de maatschappelijke en culturele werkers n.e.g. (zie tabel 3.6. en bijlage 3) Het percentage vrouwen varieert van $24 \%$ voor de overige wetenschappelijke e.a. vakspecialisten tot $62 \%$ voor de taalkundigen e.d.

Tabel 3.7. Procentuele verdeling van de werkzame personen in 1985 naar opleidingsniveau (SOI 1e digit) en CBS- en ROA-beroepsklassen

\begin{tabular}{lccccc}
\hline & BASISONDERWIJS & AVO-LT/LBO & AVO-HT/MBO & HBO & WO \\
\hline CBS-klasse & $\%$ & $\%$ & $\%$ & $\%$ & $\%$ \\
19 & 1 & 3 & 20 & 47 & 29 \\
ROA-klasse & & & & & \\
1131 & 3 & 5 & 18 & 34 & 40 \\
7031 & 1 & 2 & 25 & 56 & 16 \\
7032 & 0 & 3 & 33 & 57 & 6 \\
7033 & 1 & 2 & 11 & 64 & 11 \\
7034 & 0 & 3 & 22 & 17 & 69 \\
7035 & 1 & & & & 57 \\
\hline
\end{tabular}

Bron: CBS/ROA

Uit de ROA-codering (het derde cijfer is immers steeds een 3) blijkt reeds dat het om beroepsklassen gaat met als mediaan niveau een hogere opleiding. De sociologen, psychologen e.a. sociale wetenschapsbeoefenaren en de overige wetenschappelijke e.a. vakspecialisten kan men zelfs bestempelen als academische beroepen: het aandeel van academici in de werkzame 
personen bedraagt respectievelijk $69 \%$ en $57 \%$. Voor de taalkundigen e.d. is het percentage HBO- en WO-opgeleiden ongeveer even groot (34\% versus $40 \%$ ). In de andere ROA-beroepsklassen van bibliothecarissen, maatschappelijke en culturele werkers n.e.g., alsmede van personeelsspecialisten e.d. heeft meer dan de helft van het aantal werkenden in 1985 een HBOopleiding als achtergrond (zie tabel 3.7. en bijlage 4).

\section{Overige administratieve functies (CBS-code 39)}

De CBS-beroepsklasse 'overige administratieve functies' is de grootste beroepsklasse in de CBSindeling. In 1985 waren er volgens de AKT-cijfers 380.000 werkenden in deze beroepsklasse, waarvan $50 \%$ vrouwen. De zes onderliggende CBS-beroepsgroepen worden in de ROA-indeling geclusterd tot 3 nieuwe beroepsklassen (tussen haakjes staat opnieuw de ROA-code):

- bibliotheek-, archiefemployees (6123);

- employees goederenexpeditie, magazijn- en voorraadadministratie e.d. (6125);

- materiaal- en produktieplanners, (niet technische) werkvoorbereiders (6125);

- correspondenten en ander administratiepersoneel n.e.g. (6125);

- receptionisten, reisbureau-employees e.d. (6126);

- overige administratieve functies (6126).

Tabel 3.8. Aantal werkzame personen in 1985 naar CBS en ROA-beroepsklassen en geslacht

\begin{tabular}{|c|c|c|c|c|}
\hline & CBS-groepen & mannen & vrouwen & totaal \\
\hline \multicolumn{5}{|c|}{ CBS-klasse } \\
\hline 39 & 391-399 & 188.300 & 191.500 & 379.800 \\
\hline \multicolumn{5}{|c|}{ ROA-klasse } \\
\hline $\begin{array}{l}6123 \\
6125\end{array}$ & $\begin{array}{r}395 \\
391-393\end{array}$ & $\begin{array}{r}9.600 \\
165.300\end{array}$ & $\begin{array}{r}11.300 \\
141.200\end{array}$ & $\begin{array}{r}20.800 \\
306.500\end{array}$ \\
\hline 6126 & $380^{23}+394+399$ & 16.700 & 53.600 & 70.300 \\
\hline
\end{tabular}

Bron: CBS/ROA

De ROA-beroepsklasse van commercieel-administratieve employees (ROA-code 6125) is met 306.000 werkenden, waaronder $46 \%$ vrouwen, veruit de grootste groep. De CBS-beroepsgroep 393 van correspondenten e.a. administratiepersoneel vormt hierin met 258.000 werkenden de

23. In de ROA-indeling wordt onder code 6126 overigens ook de CBS-beroepsgroep 380 van telefonisten, telegrafisten e.d. opgenomen. 
belangrijkste component. De ROA-beroepsklasse van telefonisten, balie-employees, enquêteurs e.d. (ROA-code 6126) telt volgens de arbeidskrachtentelling in 198570.300 werkenden, waaronder $76 \%$ vrouwen. De ROA-beroepsklasse van bibliotheekassistenten is met 20.800 werkenden (waaronder $54 \%$ vrouwen) de kleinste beroepsklasse van deze drie economischadministratieve beroepscategorieën.

In de ROA-indeling worden de bovengenoemde administratieve functies ingedeeld in de beroepssector van de economisch-administratieve beroepen en hebben zij alle drie, zoals uit de tweede digit van de ROA-code blijkt, opleidingsniveau 2, wat wil zeggen dat het mediane opleidingsniveau middelbaar is. Voor deze beroepsklassen geldt dat de helft van de werkenden een MBO- of HAVO/VWO-opleiding heeft gevolgd en ongeveer $30 \%$ een LBO- of MAVOopleiding.

Tabel 3.9. Procentuele verdeling van de werkzame personen in 1985 naar opleidingsniveau (SOI 1e digit) en CBS- en ROA-beroepsklassen

\begin{tabular}{lccccc}
\hline & BASISONDERWIJS & AVO-LT/LBO & AVO-HT/MBO & HBO & WO \\
\hline CBS-klasse & $\%$ & $\%$ & $\%$ & $\%$ & $\%$ \\
39 & 7 & 32 & 51 & 8 & 1 \\
ROA-klasse & & & & & \\
6123 & 5 & 31 & 51 & 12 & 1 \\
6125 & 7 & 32 & 51 & 8 & 2 \\
6126 & 8 & 32 & 49 & 9 & 1 \\
\hline
\end{tabular}

Bron: CBS/ROA

Met betrekking tot het presenteren van arbeidsmarktinformatie geldt dat er helaas nog steeds een grote beroepsklasse overblijft, maar ook hier hebben we te maken met het feit dat deze grote klasse voor een belangrijk deel reeds op beroepsgroepniveau bestaat ${ }^{24}$. Deze grote beroepsgroep 393 (correspondenten e.a. administratiepersoneel n.e.g.) is op zichzelf overigens ook weer een heterogene verzameling van beroepen. $\mathrm{Zij}$ omvat naast correspondenten, personeelsadministratie-employees, notaris- en rechtbankklerken, verzekeringsemployees,

24. Deze ROA-beroepsklasse had in principe circa $15 \%$ kleiner kunnen indien de CBSberoepsgroepen 391 en 392 (samen nog geen 50.000) niet bij beroepsgroep 393 in én ROA-klasse waren gevoegd. Gezien de grote overeenkomsten tussen deze drie beroepsgroepen voor wat betreft het opleidingsprofiel, de werkzaamheden en de grote verscheidenheid aan functies binnen beroepsgroep 393 , is het echter reëler de beroepsgroepen 391 en 392 bij de beroepsgroep 393 te voegen. 
commercieel medewerkers, evenals ambtenaren, welke ondergeschikt zijn aan de uitvoerende hoofdambtenaars.

In het algemeen kan geconcludeerd worden dat met name bij de beroepen in de administratieve sfeer de CBS-classificatie ook op het niveau van beroepsgroepen onderscheidingsvermogen te kort komt. De nadruk in de diversificatie ligt op de industrieberoepen, die vertaald naar het aantal werkenden, de afgelopen decennia juist aan belang hebben ingeboet.

\subsection{Enkele arbeidsmarktindicatoren}

Als laatste willen we de CBS- en de ROA-beroepenclassificaties vergelijken met behulp van enkele arbeidsmarktindicatoren, die elk een specifiek aspect van de structuur en dynamiek van de arbeidsmarkt weergeven. Achtereenvolgens wordt ingegaan op de sexespecifieke beroepssegregatie-indices s en S (zie Siegers, 1979 en Van Mourik en Siegers, 1988) en de GiniHirschman-coëfficiënten als indicatoren voor de opleidingen- en branchespreiding per beroepsklasse (zie Wieling e.a., 1990).

\subsubsection{Sexespecifieke beroepssegregatie}

De segregatie-indices $\mathrm{s}$ en $\mathrm{S}$ zijn maatstaven om de scheiding tussen mannen- en vrouwenberoepen te kwantificeren. De index $s$ geeft aan "hoe groot de som bedraagt van het percentage van de mannelijke en de vrouwelijke beroepsbevolking, dat van beroep dient te veranderen, opdat de procentuele verdeling van het aantal beroepsbeoefenaren over de onderscheiden beroepsklassen voor mannen en vrouwen dezelfde is" (Siegers, 1979, blz. 209). Bij de index $\mathrm{S}$ geldt bovendien als restrictie, dat "de verdeling van de totale beroepsbevolking over de onderscheiden beroepsklassen ongewijzigd blijft" (Siegers, 1979, blz. 210). Deze indices zijn voor zowel de CBS-, als de ROA-beroepsklassen berekend (zie tabel 3.10.). ${ }^{25}$

De verwachtingen ten aanzien van de verschillen tussen de CBS-en ROA-beroepsklassen voor wat betreft de waarden van de segregatie-indices zijn niet eenduidig. Het gebruik van de ROAberoepklassenindeling in plaats van die van het CBS heeft volgens ons namelijk twee elkaar compenserende effecten. Enerzijds zijn in de ROA-beroepsklassenindeling een aantal dienstverlenende en administratieve beroepen, waarin vrouwen juist sterk zijn

25. Hierbij zijn de indices berekend voor de werkzame personen, in tegenstelling tot Siegers (1979) en Van Mourik en Siegers (1988) die de indices voor de beroepsbevolking hebben berekend. Voor een precieze interpretatie van de indices $\mathrm{S}$ en $\mathrm{S}$ wordt eveneens verwezen naar Siegers (1979) en Van Mourik en Siegers (1988). 
oververtegenwoordigd, verder onderverdeeld, hetgeen een stijging van de segregatie-indices tot gevolg heeft. Anderzijds zijn de technisch-ambachtelijke beroepsklassen, die meestal 'mannenberoepen' bevatten, door het ROA bij elkaar gevoegd, waardoor de waarde van beide segregatiemaatstaven juist zal dalen. Naast deze twee effecten, verwachten we dat de segregatie-indices voor de ROA-beroepsklassen lichtelijk hoger zijn, dan die voor de CBSberoepsklassen, aangezien de ROA-Beroepenclassificatie een tiental beroepsklassen meer onderscheidt, dan de CBS-classificatie. De waarden van de indices lopen immers op, naarmate de indeling verfijnder wordt (Tijdens, 1990; Siegers, 1979) ${ }^{26}$.

Tabel 3.10. Sexespecifieke beroepssegregatie-indices $s$ en $S$ voor de CBS- en ROA-beroepsklassen op basis van werkzame personen in AKT 1985

S S

$\begin{array}{lll}\text { CBS-beroepsklassen } & 59,27 & 26,56 \\ \text { ROA-beroepsklassen } & 59,83 & 26,85\end{array}$

Bron: CBS/ROA

Tabel 3.10. laat zien dat de waarde van beide segregatie-indices nauwelijks verschillen laten zien tussen de ROA- en CBS-classificatie. De grote mate van overeenkomst tussen de segregatie-indices van de CBS- en ROA-beroepsklassen duidt er in ieder geval op, dat, ook bij het gebruik van de ROA-Beroepenclassificatie, de beroepssegregatie tussen mannen en vrouwen in belangrijke mate wordt gemeten. Hoewel vooralsnog het hanteren van de ROA- in plaats van de CBS-beroepsklassenindeling de waarden van de segregatie-indices (mede) door een tweetal elkaar compenserende effecten nauwelijks lijkt te beïnvloeden, is het wellicht toch zinvoller om voor het meten van de sexespecifieke beroepssegregatie de ROA-Beroepenclassificatie als uitgangspunt te nemen. De segregatie-indices zijn er namelijk op gericht de scheiding tussen (mannelijke en vrouwelijke) arbeidsmarktsegmenten te kwantificeren. Zoals reeds in de vorige paragraaf is gebleken, komen de ROA-beroepsklassen meer overeen met de feitelijke binnen de arbeidsmarkt bestaande deelmarkten, dan de huidige CBS-beroepsklassen.

\subsubsection{Opleidingenspreiding}

Vervolgens bespreken we in dit hoofdstuk de arbeidsmarktindicator die betrekking heeft op de relatie tussen opleiding en beroep. Deze relatie is namelijk in de praktijk doorgaans geen

26. Op basis van de AKT 1985 blijkt dat de index $S$ varieert van 17,83 voor de 8 CBSberoepssectoren, via 26,19 voor de ruim 80 CBS-beroepsklassen tot 28,66 voor de circa 320 CBS-beroepsgroepen (Tijdens, 1990, blz. 20). 
exclusieve relatie, in de zin dat één opleiding opleidt tot één beroep. Er bestaat meestal een zekere flexibiliteit in de aansluiting tussen opleiding en beroep. In het ROA-informatiesysteem onderwijs-arbeidsmarkt wordt de Gini-Hirschman-index (GH-index) gebruikt om deze flexibiliteit op de arbeidsmarkt aan te geven ${ }^{27}$. In het studie- en beroepskeuzesysteem I-See!, dat haar gegevens voor de arbeidsmarktmodule ontleent aan het ROA-informatiesysteem, wordt de $\mathrm{GH}$ index toegepast om de beroepenspreiding van de verschillende opleidingscategorieën aan te geven. Voor een vergelijking tussen de CBS- en ROA-Beroepenclassificatie is het interesanter te kijken naar de omgekeerde spreidingsmaatstaf: de opleidingenspreiding voor de verschillende beroepsklassen ${ }^{28}$. De index is dan een maatstaf voor de mate waarin een bepaalde beroepsklasse uit beroepsbeoefenaren bestaat met verschillende opleidingsachtergronden. Met andere woorden: in hoeverre hebben de beroepsklassen homogene dan wel heterogene opleidingsprofielen? De GH-maatstaf wordt als volgt berekend:

$$
G H_{b}=\left(1-\sum_{0=1}^{0} \frac{\left(W P_{b o}\right)^{2}}{W P_{b}} \frac{(0)}{0-1}\right.
$$

$\mathrm{GH}_{\mathrm{b}}=$ opleidingenspreiding van beroep $\mathrm{b}$;

$\mathrm{O}=$ het aantal onderscheiden opleidingen;

$W P_{b o}=$ het aantal werkzame personen in beroepsklasse $b$, opleiding o;

$W P_{b}=$ het aantal werkzame personen in beroepsklasse $b$.

De indicator kan waarden aannemen tussen 0 en 1 . De indicator is 0 als de beroepsklasse bestaat uit beroepsbeoefenaren, die allemaal dezelfde opleiding als hoogst genoten onderwijs hebben gevolgd. De opleidingenspreiding bedraagt 1 als alle opleidingen in dezelfde mate zijn vertegenwoordigd in de beroepsklasse.

Een hoge waarde van de index voor een bepaalde beroepsklasse kan een tweetal oorzaken hebben. Aan de ene kant kan een beroepsklasse zijn opgebouwd uit, qua opleidingsprofielen, verschillende beroepsgroepen of beroepen. In dit geval is een sterke opleidingenspreiding dus te wijten aan een (te) heterogeen samengestelde beroepsklasse. Aan de andere kant kan er daadwerkelijk sprake zijn van een gevarieerde opleidingsachtergrond van de werkenden voor alle beroepen en beroepsgroepen in de betreffende beroepsklasse. Een lage waarde van de index geeft daarentegen aan dat er een nauwe relatie bestaat tussen een beroepsklasse en een

27. Zie voor een overzicht van (mogelijke) arbeidsmarktindicatoren De Grip en Heijke (1988) en Wieling, De Grip en Willems (1990).

28. De opleidingenspreiding is berekend op basis van de bijna zestig opleidingen die het ROA ten behoeve van I-SEE! onderscheidt (zie ook bijlage 9). 
bepaalde opleiding.

Daar de ROA-beroepsklassenindeling is geconstrueerd op basis van een clusteranalyse, waarbij de beroepsgroepen met een gelijke opleidingsachtergrond bij elkaar zijn gevoegd, kan worden verwacht dat de opleidingenspreiding voor de ROA-beroepsklassen lager is dan voor de CBSberoepsklassen ${ }^{29}$. Hiervoor wordt gekeken naar de procentuele verdeling van zowel de CBS-, als ROA-beroepsklassen over de verschillende grootteklassen van de $\mathrm{GH}$-indicator van de opleidingenspreiding (zie tabel 3.11. en bijlage 5).

Tabel 3.11. Procentuele verdeling van de CBS- en ROA-beroepsklassen naar grootteklasse van de GiniHirschman-index voor de opleidingenspreiding volgens AKT 1985

\begin{tabular}{lcr}
$\begin{array}{l}\text { Opleidingenspreiding } \\
\text { GH-index }\end{array}$ & $\begin{array}{c}\text { CBS-indeling } \\
\%\end{array}$ & $\begin{array}{r}\text { ROA-inde } \\
\%\end{array}$ \\
\hline $0,00-0,20$ & 0 & 3 \\
$0,21-0,40$ & 1 & 3 \\
$0,41-0,60$ & 4 & 5 \\
$0,61-0,80$ & 42 & 46 \\
$0,81-1,00$ & 53 & 43
\end{tabular}

Bron: $\mathrm{CBS} / \mathrm{ROA}$

Zoals is te zien in tabel 3.11. zijn de Gini-Hirschman-coëfficiënten van de opleidingenspreiding voor de ROA-beroepsklassen vaker lager, dan de coëfficiënten voor de CBS-beroepsklassen. De ROA-beroepsklassen kunnen, voor wat betreft de opleidingsachtergrond van de beroepsbeoefenaren, dus homogener worden genoemd dan de CBS-beroepsklassen, hetgeen een logisch gevolg is van het criterium dat ten grondslag heeft gelegen aan de clusteranalyse. Deze hogere homogeniteit is met name van groot belang voor de beroepsklassen, die voorheen, naar opleidingsachtergrond, nogal heterogeen waren samengesteld.

Een duidelijk voorbeeld van een dergelijke beroepsklasse is de CBS-beroepsklasse 06/07 van genees- en verpleegkundigen e.d. Deze heeft voor de opleidingenspreiding een zeer hoge GiniHirschman-index (namelijk 0,89). Wanneer wordt gekeken naar deze indices voor de (para)medische ROA-beroepsklassen, dan blijkt de hoge index voor deze CBS-beroepsklasse voornamelijk het gevolg te zijn van het feit, dat het CBS de (para)medische beroepsgroepen, die wat betreft de opleidingsprofielen dikwijls sterk van elkaar afwijken, in één beroepsklasse heeft samengevoegd. Zo blijkt dat de geneeskundige ROA-beroepenklassen met academisch geschool-

29. Althans voor zover een CBS-beroepsgroep geen beroepen omvat, die qua opleidingsprofiel sterk afwijkend zijn. In dat geval zal de index niet (kunnen) afnemen. 
de beroepsbeoefenaren, als ook de ROA-beroepsklasse apothekersassistenten en in mindere mate de beroepsklasse gediplomeerde verpleeg- en verloskundigen een (zeer) kleine opleidingenspreiding hebben. Bij deze beroepsklassen bestaat er dus een nauwe relatie tussen de gevolgde opleiding en het beroep. Dit komt echter pas tot uiting bij het hanteren van de ROA-beroepsklassenindeling. De hoge opleidingenspreidingsindices voor de andere (para)medische ROA-beroepsklassen duiden enerzijds op het feit, dat voor bepaalde beroepen, zoals leerling-verpleegkundigen en ziekenverzorgenden, alsmede (dieren- en tand)artsassistenten, mensen gerecruteerd worden met diverse opleidingsachtergronden. Anderzijds zijn deze hoge indices het gevolg van het feit, dat een aantal (para)medische beroepsgroepen zijn samengesteld uit, naar opleidingsprofiel (en aard van de werkzaamheden), sterk uiteenlopende beroepen. Dit geldt bijvoorbeeld voor CBS-beroepsgroep 079 (ROA-beroepsklasse 5025), waarin zowel EEG-laboranten, keurmeesters, logopedisten, als inspecteurs voor de volksgezondheid zijn opgenomen. Aangezien deze CBS-beroepsgroepen de bouwstenen hebben gevormd van onze clusteranalyse, blijft deze heterogeniteit op een hoger aggregatieniveau bestaan.

Dat de index voor de CBS-beroepsklasse (sociaal) wetenschappelijke en andere vakspecialisten hoog is, (namelijk 0,83) ligt ook in de lijn der verwachting. In de naam van de CBSberoepsklasse wordt immers reeds aangegeven dat het een zeer diverse verzameling van beroepen betreft. Omdat ook op het CBS-beroepsgroepenniveau de samenstelling nog erg divers is blijft de opleidingenspreidings-index voor de desbetreffende (sociaal) culturele ROAberoepsklassen eveneens hoog. De index varieert voor deze beroepsklassen van 0,67 tot 0,93. Door het gebruik van de ROA-beroepsklassenindeling kan men binnen deze CBS-beroepsklasse van diverse (wetenschappelijke) vakspecialisten nu echter wel een onderscheid maken tussen beroepsklassen met enerzijds HBO- en anderzijds academische onderwijsprofielen (zie ook tabel 3.7., paragraaf 3.2.). De hoge opleidingenspreiding bij de ROA-beroepsklassen heeft dan ook vooral betrekking op de spreiding naar vakrichting, in plaats van op een spreiding naar opleidingsniveau.

Ook de CBS-beroepsklasse overig administratief personeel heeft een hoge index voor de opleidingenspreiding: 0,90. De overeenkomstige administratieve ROA-beroepsklassen hebben vergelijkbaar hoge indexwaarden $(0,90$ tot 0,92$)$. Voor een deel is dit opnieuw terug te voeren op het feit dat de ROA-beroepsklassen zijn opgebouwd uit qua opleidingsachtergrond heterogene beroepsgroepen. Voor een ander deel wijst de hoge spreidingsmaatstaf in de richting van een gevarieerde opleidingsachtergrond van de werkenden in alle beroepen in de desbetreffende beroepsklassen. Ten aanzien van deze beroepsklassen lijkt er dus een grotere flexibiliteit te bestaan tussen het genoten onderwijs en het beroep dat men uitoefent. 
De opleidingenspreidingscoëfficiënt voor de CBS-beroepsklasse (CBS-code 13) is met 0,56 relatief laag te noemen. In de ROA-indeling wordt deze CBS-klasse verder onderverdeeld in drie beroepsklassen. Daardoor is nu goed te zien, dat er binnen deze CBS-beroepsklasse beroepen zijn met zowel homogene, als heterogene opleidingsprofielen (zie ook tabel 3.5., paragraaf 3.2.). Zo heeft de ROA-beroepsklasse van leerkrachten voor het basis- en buitengewoon onderwijs een opleidingenspreiding van 0,24 , terwijl daarentegen de spreidingscoëfficiënt voor de schoolhoofden e.a. onderwijskundige beroepen 0,86 bedraagt. Ook hier wordt de hoge waarde van de maatstaf voor de laatst genoemde beroepsklasse voor een belangrijk deel veroorzaakt door de heterogene samenstelling van de desbetreffende beroepsgroep (CBS-code 139). Doordat deze beroepsgroep in de ROA-beroepsklassenindeling van de zuivere onderwijskundige functies wordt gescheiden, komt de sterke relatie tussen de specifieke leerkrachtenopleidingen en de docentschappen echter wel beter tot uiting.

Ondanks de aanzienlijke samenvoeging van de technisch-ambachtelijke beroepsgroepen in de ROA-Beroepenclassificatie zijn de coëfficiënten met betrekking tot de opleidingenspreiding voor de technisch-ambachtelijke beroepsklassen nauwelijks gewijzigd. Deze beroepsklassen zijn door de sterke clustering dus qua opleidingsprofiel niet heterogener geworden. Blijkbaar gaat het hier niet om verschillende arbeidsmarktsegmenten, zodat een verdergaande clustering van deze beroepsgroepen verantwoord is.

Uit het overzicht van de spreiding van de opleidingen per beroepsklasse blijkt dat de ROAindeling inderdaad, zoals verwacht mocht worden, homogener is voor wat betreft de opleidingsachtergrond van de werkenden. De uitkomsten van deze spreidingsmaatstaf bevestigen dat de nieuwe ROA- beroepsklassen de in een aantal gevallen nauwe relatie tussen beroep en opleiding beter weerspiegelen dan de CBS-beroepsklassen. Voor het genereren en presenteren van informatie over de relatie tussen onderwijs en arbeidsmarkt is een indeling die nauw aansluit bij de feitelijk bestaande arbeidsmarktsegmenten uiteraard van groot belang.

\subsubsection{Branchespreiding}

Naast de opleidingenspreiding van beroepen kan ook de branchespreiding per beroepsklasse worden bepaald. Analoog aan de opleidingenspreiding, geeft een lage branchespreiding aan dat in een beroepsklasse slechts werkenden uit één (de coëfficiënt is dan 0) of enkele branches c.q. (bedrijfssectoren ${ }^{30}$ ) vóórkomen. Een hoge branchespreiding duidt op een gelijkmatige verdeling

30. Hiervoor zijn de bedrijfssectoren gehanteerd, die het ROA voor de arbeidsmarktinformatie van I-SEE! gebruikt. Deze indeling is gebaseerd op de CPB-bedrijfssectoren, die een aggregatie vormen van de SBI-bedrijfsklassen van het CBS (zie ook bijlage 7). 
van de branches in een bepaalde beroepsklasse. Zoals gezegd, kan dit laatste deels een gevolg zijn van een samenvoeging van beroepen en in beroepsgroepen die, naar de branches waarin men werkzaam is, ver uiteen liggen. Uiteraard kan een hoge index ook wijzen op een heterogeen brancheprofiel, dat voor alle beroepsgroepen en beroepen in de betreffende beroepsklasse geldt.

We vergelijken de uitkomsten voor de beide beroepsklassenindelingen om na te gaan of de nieuwe beroepenclassificatie van het ROA homogener is voor wat betreft de branches waarin bepaalde categorieën beroepsbeoefenaren werkzaam zijn. Immers indien een heterogene CBSberoepsklasse wordt gesplitst in meerdere ROA-beroepsklassen, zou men mogen verwachten dat de coëfficiënt voor de branchespreiding ook lager wordt. Daartegenover staat dat de CBSBeroepenclassificatie sterke raakvlakken heeft met de Standaard Bedrijfsindeling. De ROABeroepenclassificatie is daarentegen, zoals gezegd, juist gebaseerd op de opleidingsachtergrond van de beroepsbeoefenaren. Bovendien zijn bij de clustering een groot aantal technischambachtelijke beroepen samengevoegd, welke door het CBS dikwijls onderverdeeld zijn naar een specifieke bedrijfstak. De laatste twee redenen zouden tot een stijging van de waarde van de maatstaf bij de ROA-beroepsklassen kunnen leiden.

Wanneer wordt gekeken naar de verschillen in branchespreidingscoëfficiënten tussen de beide beroepenindelingen valt op, dat de CBS-beroepsklassen vaker een lage branchespreiding hebben, dan de ROA-beroepsklassen (zie tabel 3.12. en bijlage 8). Terwijl van de CBSberoepsklassen $56 \%$ een waarde heeft van 0,60 of lager, heeft van de ROA-beroepsklassen slechts $43 \%$ een dergelijke branchespreidingscoëfficiënt. Bovendien is de mediaan van de branchespreiding bij de CBS-beroepsklassen lager dan bij de ROA-beroepsklassen: 0,55 versus 0,67. De CBS-beroepsklassen hebben door de bank genomen derhalve een meer homogene sectorstructuur, dan de ROA-beroepsklassen.

Tabel 3.12. Procentuele verdeling van de CBS- en ROA-beroepsklassen naar grootteklasse van de GiniHirschman-index voor de branchespreiding volgens AKT 1985

$\begin{array}{lcc}\text { Branchespreiding } & \text { CBS-indeling } & \text { ROA-indeling } \\ \text { GH-index } & \% & \%\end{array}$

$\begin{array}{lll}0,00-0,20 & 23 & 18 \\ 0,21-0,40 & 16 & 12 \\ 0,41-0,60 & 17 & 13 \\ 0,61-0,80 & 21 & 30 \\ 0,81-1,00 & 23 & 27\end{array}$


De afname in homogeniteit naar sector blijkt overigens nauwelijks toe te schrijven aan de vergaande clustering van de technisch-ambachtelijke beroepsgroepen bij de ROA-indeling; terwijl van de technisch-ambachtelijke CBS-beroepsklassen (code 70-99) 60\% een branchespreidingscoëfficiënt heeft van 0,60 of lager, heeft van de overeenkomstige ROA-beroepsklassen (sector 3 en 4 ; niveau 1) $43 \%$ een dergelijke lage sectorspreiding. Het verschil in de percentages tussen beide beroepenindelingen is dus voor de technisch-ambachtelijke beroepsklassen vrijwel gelijk aan die voor alle beroepsklassen.

De hoogste spreidingscoëfficiënten kan men zowel bij de CBS-, als de ROA-Beroepenclassificatie bij een drietal soorten beroepsklassen aantreffen. Ten eerste gaat het hier om de heterogeen samengestelde beroepsklassen, zoals bijvoorbeeld CBS-klasse 97, waarin zowel laad- en lospersoneel, als kraan- en hijsmachinisten en heftruckchauffeurs zijn opgenomen. Ten tweede heeft ook de gebruikte bedrijfssectorindeling invloed op de resultaten van de branchespreiding. De industriële bedrijfssector wordt namelijk opgedeeld in 10 subsectoren, terwijl de andere (agrarische en dienstverlenende) sectoren nauwelijks verder zijn gesplitst. Beroepen, die zo goed als alleen vórkomen in de industrie, maar wel in meerdere industrietakken zijn vertegenwoordigd kunnen op deze wijze, ondanks hun gerichtheid op de industrie, toch een hoge coëfficiënt voor de branchespreiding hebben. Dit geldt bijvoorbeeld voor de ROA-beroepsklasse 3622 (middelbare werktuigkundigen e.a. metaalkundigen). Ten derde hebben met name de zogenaamde 'procesgebonden beroepen' dikwijls een grote branchespreiding. Arbeidskrachten in dergelijke 'procesgebonden' functies hebben in feite een taak als begeleider van het produktieproces. Dit in tegenstelling tot de 'produktgebonden' functies, waarin men gericht is op het vervaardigen van een bepaald produkt. Produktgebonden functies hebben daardoor vaak een directe relatie met een bepaalde bedrijfssector. Procesgebonden functies zijn daarentegen het algemeen niet beperkt tot bepaalde bedrijfssectoren, aangezien hun werkzaamheden in alle bedrijfssectoren vervuld dienen te worden. Zowel de leidinggevende als administratieve functies kunnen bijvoorbeeld tot deze 'procesgebonden functies' worden gerekend. De beroepsklassen die bestaan uit deze 'procesgebonden functies' blijken dan ook dikwijls een grote branchespreiding te kennen. Omgekeerd hebben beroepsklassen die (sectorspecialistische) 'produktgebonden functies' omvatten meestal een kleine branchespreiding.

Hierna zullen we de branchespreiding voor de vier eerder in dit hoofdstuk besproken CBSberoepsklassen beschrijven. De heterogene en omvangrijke CBS-beroepsklasse 06/07 heeft een branchespreidingscoëfficiënt van 0,31 . Wanneer deze beroepsklasse wordt gesplitst in een negental ROA-beroepsklassen blijkt de sectorspreiding te variëren van 0,04 voor de tandheelkundigen tot 0,53 voor de radiologische, medische en biologische laboranten, die niet alleen 
in de gezondheidszorg, maar eveneens in de industrie werkzaam blijken te zijn. De overige (para)medische ROA-beroepsklassen hebben allemaal een (zeer) lage coëfficiënt voor de sectorspreiding. Alleen ROA-beroepsklasse 5025, die de heterogene CBS-beroepsgroep 079 van EEG-laboranten, logopedisten en inspecteurs voor de volksgezondheid omvat, heeft een in verhouding hoge sectorspreidingsindex van 0,42. Door het gebruik van de ROAberoepsklassenindeling wordt het nu inzichtelijker welke (para)medische beroepen een nauwe relatie hebben met één of enkele branches en welke (para)medische beroepen in een breed scala van branches zijn vertegenwoordigd.

Voor de ROA-beroepenindeling hebben de leerkrachten (code 0131 en 0132) de laagste branchespreidingscoëfficiënten, namelijk 0,0068 en 0,0009. Hoewel de leerkrachten ook bij de CBS-indeling een lage branchespreidingscoëfficiënt hebben $(0,0939)$, ligt de waarde van de coëfficiënt toch aanmerkelijk hoger. Dit is toe te schrijven aan de beroepsgroep 139, directeuren van scholen en andere onderwijskundige functies, die in de ROA-indeling is afgezonderd van de strikt onderwijsgevende functies. Deze ROA-beroepsklasse heeft namelijk een veel hogere branchespreidingscoëfficiënt $(0,6543)$. De beroepsbeoefenaren in deze ROAberoepsklasse blijken namelijk regelmatig, bijvoorbeeld als bedrijfsopleidingsfunctionaris, in andere sectoren dan het onderwijs werkzaam.

De (sociaal) wetenschappelijke e.a. vakspecialisten (CBS-code 19) hebben een hoge spreidingscoëfficiënt $(0,72)$, hetgeen voor een deel de heterogene samenstelling van deze CBSberoepsklasse lijkt te weerspiegelen. In de ROA-indeling zijn de onderliggende beroepsgroepen allen in een afzonderlijke ROA-beroepsklasse opgenomen, waardoor we verwachten dat de branchespreiding afneemt. Bij deze (sociaal) culturele ROA-beroepsklassen varieert de branchespreidingsmaatstaf echter van 0,5216 voor de klasse van maatschappelijk werkers en reclasseringsambtenaren (ROA-code 7033) tot 0,8841 voor die van personeels-, beroepenspecialisten en arbeidsbemiddelaars. Enerzijds is dit een gevolg van de diversiviteit van de beroepen die in de betreffende beroepsgroepen (en ROA-klassen) zijn vertegenwoordigd. Anderzijds gaat het hier om beroepsklassen, waarin voor alle daarin opgenomen dikwijls 'procesgebonden' beroepsgroepen en beroepen geldt, dat de beroepsbeoefenaren in een uiteenlopend scala van bedrijfssectoren werkzaam zijn.

De CBS-beroepsklasse van de overige administratieve functies heeft een branchespreiding van 0,9156. Deze hoge spreiding is te verwachten op grond van het feit dat de onderliggende administratieve 'procesgebonden functies' in de meeste sectoren zijn vertegenwoordigd. Deze CBS-beroepsklasse is in de ROA-indeling terug te vinden in de beroepsklassen 6123 van bibliotheek- en archiefemployees, 6125 van commercieel-administratieve employees en 6126 
$-33-$

van telefonisten, balie-employees en enquêteurs e.d. De spreidingsmaatstaf bedraagt respectievelijk 0,$7779 ; 0,9145$ en 0,9239. Ook voor de ROA-beroepsklassen vinden we dus hoge spreidingscoëfficiënten.

In het algemeen geldt derhalve dat de sectorspreiding voor de CBS-indeling lager is dan die voor de ROA-indeling, hetgeen verwacht kon worden, gezien het feit dat deze beroepenindeling deels een sectorspecifieke invalshoek kent. Toch hebben we ook kunnen constateren, dat door de nieuwe ROA-indeling bij een aantal (voorheen heterogene) CBS-beroepsklassen de sectorspreidingscoëfficiënt is gedaald, hetgeen er op wijst, dat de nieuwe indeling voor deze beroepsklassen ook meer homogeen is voor wat betreft de sectorstructuur. 


\section{BESLUIT}

Zoals gezegd, was het doel van de hergroepering van de CBS-beroepsgroepen, het samenstellen van beroepsklassen, die een beter inzicht geven in de feitelijke arbeidsmarktsegmenten. Het uitgangspunt voor deze hergroepering vormde de opleidingsprofielen van de beroepsgroepen. $\mathrm{De}$ achterliggende gedachte daarbij was dat beroepsgroepen met dezelfde opleidingsprofielen tot eenzelfde arbeidsmarktsegment gerekend kunnen worden.

Aangezien de ROA-beroepsklassen qua opleidingsachtergrond meer homogeen blijken te zijn dan de CBS-beroepsklassen, kan men ons inziens stellen, dat de ROA-beroepsklassen beter geschikt zijn voor het genereren en presenteren van arbeidsmarktinformatie dan de huidige CBSberoepsklassen. Bovendien heeft de ROA-Beroepenclassificatie het voordeel, dat zij op verschillende, duidelijk afgebakende, analyseniveaus gehanteerd kan worden.

Hoewel de in dit werkdocument gepresenteerde beroepenindeling derhalve als een verbetering van de huidige CBS-Beroepenclassificatie gezien kan worden, blijft ook de ROA-indeling zeker voor verbetering vatbaar. Het belangrijkste probleem bij het hergroeperen van de CBSberoepsgroepen tot nieuwe beroepsklassen werd gevormd door de heterogeniteit van sommige CBS-beroepsgroepen. Dit maakt het onmogelijk om op een hoger aggregatieniveau na het clusteren wel homogene clusters samen te stellen. Daarmee samenhangend geldt bovendien, dat de detaillering van de verschillende beroepscategorieën van het CBS op de diverse aggregatieniveaus niet evenwichtig is ${ }^{31}$. Daarnaast blijkt ook op het laagste aggregatieniveau een aantal beroepen qua (opleidings)aard te heterogeen (zie ook De Kiewit en Teulings, 1990).

De wijze waarop het CBS een nieuwe beroepenclassificatie tot stand wil brengen ondersteunen wij dan ook van harte (zie Bakker e.a., 1989). Het CBS zou daarbij kunnen overwegen om, nadat de niet-homogene beroepen (op 4-digit) zijn gesplitst, een clusteranalyse uit te voeren op basis van een matrix van beroep (op 4-digit) naar opleiding (SOI 5-digit) met behulp van gegevens uit de AKT, dan wel de EBB. De resultaten van een dergelijke clusteranalyse zouden dan kunnen worden aangevuld met een aantal beroepenkundige criteria. Daarnaast is het van groot belang, dat het CBS duidelijke en ondubbelzinnige criteria opstelt voor een nieuwe beroepenclassificatie en deze criteria goed documenteert. Voor de gebruikers van een beroepenindeling is het immers van groot belang, dat zij de mogelijkheden hebben voor een correcte codering. Enerzijds betekent dit dat alleen afzonderlijke beroepscategorieën

31. In de beroepenclassificatie van het ROA is deze onevenwichtigheid niet helemaal verdwenen, omdat juist in de technische beroepssector de afschotting tussen de deelmarkten sterker lijkt dan in de andere beroepssectoren. 
$-35-$

onderscheiden mogen worden indien de daaraan ten grondslag gelegen verschillen ook in de beroepspraktijk bestaan. Anderzijds zullen beroepen slechts gekoppeld mogen worden aan éen beroepscode ${ }^{32}$.

32. Zo is voor een aantal van de (overige) paramedische functies (0765/0796), alsmede van de (overige) ambtenaren (3937/3998) niet eenduidig welke beroepscode gehanteerd dient te worden. 


\section{LITERATUUR}

Bakker, B.F.M., C.J. den Dulk, J.K. Jonker, J.A. Oud (1989), Een aanzet voor een nieuwe beroepenclassificatie, discussienota over de grondslagen, het ontwerp en het werkplan voor een nieuwe beroepenclassificatie, Centraal Bureau voor de Statistiek, Voorburg/Heerlen.

CBS (1984/1985), Beroepenclassificatie 1984, Centraal Bureau voor de Statistiek, Voorburg/Heerlen.

CBS (1989), Standaard Onderwijs Indeling 1978, Centraal Bureau voor de Statistiek, Voorburg/Heerlen.

CBS (1987), Arbeidskrachtentelling 1985, Centraal Bureau voor de Statistiek, Voorburg/Heerlen.

Grip, A. de, J.A.M. Heijke (1988), Arbeidsmarktindicatoren: een inventarisatie, ROA-W-1988/1, Maastricht.

Grip, A. de, L.F.M. Groot, J.A.M. Heijke (1987), Clustering occupational classes by educational structure, ROA-W-1987/2E, Maastricht.

Grip, A. de, L.F.M. Groot, J.A.M. Heijke (1991), Defining occupational groupings by educational structure, in: Environment and Planning A, 1991, volume 23, blz. 59-85.

Kiewit, J.G. de, C.N. Teulings (1990), Afbakening van beroepsdeelmarkten voor een aantal sectoren, SEO-Research Memorandum 9001, Stichting voor Economisch Onderzoek (SEO), Amsterdam.

Kiewit, J.G. de, C.N. Teulings (1990), Afbakening beroepsdeelmarkten voor de technische en administratieve sector, paper ten behoeve van Onderwijs Research Dagen (ORD) 1990, Stichting voor Economisch Onderzoek (SEO), Amsterdam.

Mourik, A. van, J. Siegers (1988), Ontwikkelingen in de beroepssegregatie tussen mannen en vrouwen, 1971-1985, in: Economisch-Statistische Berichten (ESB), 1988, blz. 732-737.

Sanderson, J. (1987), Defining functional occupational groupings, in: Environment and Planning $A, 1987$, volume 19, blz. 1199-1220.

Siegers, J. (1979), Beroepssegregatie tussen mannen en vrouwen in Nederland, in: EconomischStatistische Berichten (ESB), 1979, blz. 208-213.

Spijkerman R.M.H. (1989), Studie- en beroepskeuze, achtergronden en theorieën voor de praktijk van de dienstverlening bij studie- en beroepskeuze, Samson H.D. Tjeenk Willink, Alphen aan den Rijn.

Thomas, R., P. Elias (1989), Development of the standard occupational classification, in: Population Trends, 1989, volume 55, blz. 16-21.

Tijdens, K.G. (1990), Beroepssegregatie en werkgelegenheid, in: Tijdschrift voor Arbeidsvraagstukken, 1990/4, blz. 13-23.

Wieling, M.H., A. de Grip, E.J.T.A. Willems (1990), Een systematische kwalitatieve typering van arbeidsmarktinformatie, ROA-W-1990/8, Maastricht. 
$-37-$

BIJLAGE 1: ROA-BEROEPENCLASSIFICATIE 1990

\section{BEROEPSSECTOREN}

0 PEDAGOGISCHE BEROEPEN

1 CULTURELE BEROEPEN

2 AGRARISCHE BEROEPEN

3 TECHNISCHE, AMBACHTS- EN INDUSTRIEBEROEPEN

4 TRANSPORTBEROEPEN

5 MEDISCHE EN PARAMEDISCHE BEROEPEN

6 ECONOMISCH-ADMINISTRATIEVE BEROEPEN

7 SOCIAAL-CULTURELE BEROEPEN

8 VERZORGENDE EN DIENSTVERLENENDE BEROEPEN

9 OPENBARE ORDE- EN VEILIGHEIDSBEROEPEN 


\section{BEROEPSTAKKEN}

0 PEDAGOGISCHE BEROEPEN

01 ONDERWIJS(KUNDIGE) BEROEPEN

02 SPORT(INSTRUCTIEVE) BEROEPEN

1 CULTURELE BEROEPEN

11 TAAL- EN LETTERKUNDIGE BEROEPEN

12 THEOLOGISCHE BEROEPEN

13 KUNST- EN VORMGEVENDE BEROEPEN

2 AGRARISCHE BEROEPEN

20 AGRARISCHE BEROEPEN

3 TECHNISCHE, AMBACHTS- EN INDUSTRIEBEROEPEN

31 VOEDINGS- EN GENOTMIDDELENBEROEPEN

32 TEXTIELBEROEPEN

33 HOUT- EN PAPIERBEROEPEN

34 GRAFISCHE BEROEPEN

35 CHEMISCHE BEROEPEN

36 METAALBEROEPEN

37 ELECTROTECHNISCHE BEROEPEN

38 BOUWMATERIALEN-, GLAS- EN AARDEWERKBEROEPEN

39 BOUW- EN INSTALLATIEBEROEPEN

4 TRANSPORTBEROEPEN

41 MARITIEME E.A. WATERWEGTRANSPORTBEROEPEN

42 RAIL- EN WEGTRANSPORTBEROEPEN

43 LUCHT- EN OVERIGE TRANSPORTBEROEPEN

5 MEDISCHE EN PARAMEDISCHE BEROEPEN

50 MEDISCHE EN PARAMEDISCHE BEROEPEN

6 ECONOMISCH-ADMINISTRATIEVE BEROEPEN

61 ADMINISTRATIEVE BEROEPEN

62 COMMERCIËLE BEROEPEN

63 BESTUURLIJKE EN JURIDISCHE BEROEPEN 
$-39-$

7 SOCIAAL-CULTURELE BEROEPEN

70 SOCIAAL-CULTURELE BEROEPEN

8 VERZORGENDE EN DIENSTVERLENENDE BEROEPEN

81 HORECABEROEPEN

82 VERZORGENDE BEROEPEN

9 OPENBARE ORDE- EN VEILIGHEIDSBEROEPEN

91 POLITIE-, BRANDWEER- EN BEWAKINGSBEROEPEN

92 MILITAIRE BEROEPEN 


\section{BEROEPSSEGMENTEN}

O PEDAGOGISCHE BEROEPEN

01 ONDERWIJS(KUNDIGE) BEROEPEN

013 hogere onderwijs(kundige) beroepen

02 SPORT(INSTRUCTIEVE) BEROEPEN

022 middelbare sport(instructieve) beroepen

1 CULTURELE BEROEPEN

11 TAAL- EN LETTERKUNDIGE BEROEPEN

113 hogere taal- en letterkundige beroepen

12 THEOLOGISCHE BEROEPEN

123 hogere theologische beroepen

13 KUNST- EN VORMGEVENDE BEROEPEN

132 middelbare kunst- en vormgevende beroepen

133 hogere kunst- en vormgevende beroepen

2 AGRARISCHE BEROEPEN

20 AGRARISCHE BEROEPEN

201 lagere agrarische beroepen

203 hogere agrarische beroepen

TECHNISCHE, AMBACHTS- EN INDUSTRIEBEROEPEN

30 TECHNISCHE, AMBACHTS- EN INDUSTRIEBEROEPEN

301 lagere technische, ambachts- en industrieberoepen

302 middelbare technische, ambachts- en industrieberoepen

303 hogere technische, ambachts- en industrieberoepen

31 VOEDINGS- EN GENOTMIDDELENBEROEPEN

311 lagere voedings- en genotmiddelenberoepen

32 TEXTIELBEROEPEN

321 lagere textielberoepen

33 HOUT- EN PAPIERBEROEPEN

331 lagere hout- en papierberoepen

34 GRAFISCHE BEROEPEN

341 lagere grafische beroepen

35 CHEMISCHE BEROEPEN

351 lagere chemische beroepen

36 METAALBEROEPEN

361 lagere metaalberoepen

362 middelbare metaalberoepen

363 hogere metaalberoepen 
37 ELECTROTECHNISCHE BEROEPEN

371 lagere electrotechnische beroepen

372 middelbare electrotechnische beroepen

373 hogere electrotechnische beroepen

38 BOUWMATERIALEN-, GLAS- EN AARDEWERKBEROEPEN

381 lagere bouwmaterialen-, glas-en aardewerkberoepen

39 BOUW- EN INSTALLATIEBEROEPEN

391 lagere bouw- en installatieberoepen

392 middelbare bouw- en installatieberoepen

393 hogere bouw- en installatieberoepen

\section{TRANSPORTBEROEPEN}

40 TRANSPORTBEROEPEN

401 lagere transportberoepen

41 MARITIEME E.A. WATERWEGTRANSPORTBEROEPEN

411 lagere maritieme e.a. waterwegtransportberoepen

412 middelbare maritieme e.a. waterwegtransportberoepen

42 RAIL- EN WEGTRANSPORTBEROEPEN

421 lagere rail- en wegtransportberoepen

43 LUCHT- EN OVERIGE TRANSPORTBEROEPEN

432 middelbare lucht- en overige transportberoepen

MEDISCHE EN PARAMEDISCHE BEROEPEN

50 MEDISCHE EN PARAMEDISCHE BEROEPEN

502 middelbare medische en paramedische beroepen

503 hogere medische en paramedische beroepen

6 ECONOMISCH-ADMINISTRATIEVE BEROEPEN

60 ECONOMISCH-ADMINISTRATIEVE BEROEPEN

603 hogere economisch-administratieve beroepen

61 ADMINISTRATIEVE BEROEPEN

611 lagere administratieve beroepen

612 middelbare administratieve beroepen

613 hogere administratieve beroepen

62 COMMERCIËLE BEROEPEN

621 lagere commerciële beroepen

622 middelbare commerciële beroepen

63 BESTUURLIJKE EN JURIDISCHE BEROEPEN

633 hogere bestuurlijke en juridische beroepen 

SOCIAAL-CULTURELE BEROEPEN

70 SOCIAAL-CULTURELE BEROEPEN

702 middelbare sociaal-culturele beroepen

703 hogere sociaal-culturele beroepen

8 VERZORGENDE EN DIENSTVERLENENDE BEROEPEN

81 HORECABEROEPEN

811 lagere horecaberoepen

812 middelbare horecaberoepen

82 VERZORGENDE BEROEPEN

821 lagere verzorgende beroepen

822 middelbare verzorgende beroepen

9 OPENBARE ORDE- EN VEILIGHEIDSBEROEPEN

91 POLITIE-, BRANDWEER- EN BEWAKINGSBEROEPEN

912 middelbare politie-, brandweer- en bewakingsberoepen

92 MILITAIRE BEROEPEN

922 middelbare militaire beroepen 


\section{BEROEPSKLASSEN}

0

\section{PEDAGOGISCHE BEROEPEN}

01 ONDERWIJS(KUNDIGE) BEROEPEN

013 hogere onderwijs(kundige) beroepen

0131 leerkrachten basis- en buitengewoon onderwijs

0132 docenten voortgezet en hoger onderwijs

0133 schoolhoofden e.a. onderwijskundige beroepen

02 SPORT(INSTRUCTIEVE) BEROEPEN

022 middelbare sport(instructieve) beroepen

0221 sportinstructeurs, officials, beroepssportlieden

11 TAAL- EN LETTERKUNDIGE BEROEPEN

113 hogere taal- en letterkundige beroepen

1131 taal- en letterkundigen, vertalers, tolken

12 THEOLOGISCHE BEROEPEN

123 hogere theologische beroepen

1231 pastorale beroepen

13 KUNST- EN VORMGEVENDE BEROEPEN

132 middelbare kunst- en vormgevende beroepen

1321 fotografen, filmers, vormgevers, etaleurs

133 hogere kunst- en vormgevende beroepen

1331 beeldende en uitvoerende kunstenaars

\section{AGRARISCHE BEROEPEN}

20 AGRARISCHE BEROEPEN

201 lagere agrarische beroepen

2011 uitvoerend agrarisch personeel, bosarbeiders

2012 zelfstandige agrariërs, boswachters

203 hogere agrarische beroepen

2031 landbouwkundige vakspecialisten

TECHNISCHE, AMBACHTS- EN INDUSTRIEBEROEPEN

30 TECHNISCHE, AMBACHTS- EN INDUSTRIEBEROEPEN

301 lagere technische, ambachts- en industrieberoepen

3011 heftruck- en hefvorkchauffeurs

3012 machinisten bouw en industrie

302 middelbare technische, ambachts- en industrieberoepen

3021 leidinggevenden bouw en industrie

3022 technische en medische vertegenwoordigers

3023 technische tekenaars

3024 technische analisten, amanuenses

303 hogere technische, ambachts- en industrieberoepen

3031 bètaonderzoekers, technische vakspecialisten 
31 VOEDINGS- EN GENOTMIDDELENBEROEPEN

311 lagere voedings- en genotmiddelenberoepen

3111 voedingsmiddelenbereiders

3112 (zelfstandige) bakkers e.a. (industrieel) bakkerijpersoneel

\section{TEXTIELBEROEPEN}

321 lagere textielberoepen

3211 produktiepersoneel textielindustrie

3212 stoffeerders, schoen- e.a. lederwarenmakers

3213 kleding- e.a. textiel- en bontproduktenmakers

\section{HOUT- EN PAPIERBEROEPEN}

331 lagere hout- en papierberoepen

3311 houtzagers, hout(waren)-, papier- en kartonmakers

3312 houtbewerkers, timmerlieden

34 GRAFISCHE BEROEPEN

341 lagere grafische beroepen

3411 drukkers, boekbinders, fotolaboranten

35 CHEMISCHE BEROEPEN

351 lagere chemische beroepen

3511 produktiepersoneel chemische industrie

36 METAALBEROEPEN

361 lagere metaalberoepen

3611 delfstoffen(be)werkers, metaalvervaardigers

3612 machinale metaalbewerkers

3613 lassers, constructiewerkers, edelmetaalsmeden

3614 machinebank- en plaatwerkers, gereedschaps- en modelmakers

3615 onderhoudsmonteurs, fietsen- en instrumentmakers

362 middelbare metaalberoepen

3621 auto-, motor- en bromfietsmonteurs

3622 middelbare (scheeps) werktuigkundigen e.a. metaalkundigen

363 hogere metaalberoepen

3631 hogere werktuigkundigen

37 ELECTROTECHNISCHE BEROEPEN

371 lagere electrotechnische beroepen

3711 samenstellers electrotechnische produkten, kwaliteitscontroleurs

3712 lijnwerkers, kabelmonteurs en -lassers

372 middelbare electrotechnische beroepen

3721 electriciens, electro- en telecom(onderhouds)monteurs

3722 middelbare electrotechnici

373 hogere electrotechnische beroepen

3731 hogere electrotechnici

38 BOUWMATERIALEN-, GLAS- EN AARDEWERKBEROEPEN

381 lagere bouwmaterialen-, glas- en aardewerkberoepen

3811 produktiepersoneel bouwmaterialen-, glas en aardewerkindustrie 
391 lagere bouw - en installatieberoepen

3911 metselaars, tegelzetters, straatmakers, stukadoors

3912 betonwerkers, dakdekkers, isoleerders, glaszetters

3913 huis-, scheeps- en constructieschilders

3914 loodgieters, sanitair-installateurs en -reparateurs

3915 overige bouwvaklieden, (spoor)weg- en reinigingswerkers

392 middelbare bouw- en installatieberoepen

3921 bouwkundige technici, opzichters, werkvoorbereiders

393 hogere bouw- en installatieberoepen

3931 architecten, geodeten e.a. hogere bouwkundigen

\section{TRANSPORTBEROEPEN}

\section{TRANSPORTBEROEPEN}

401 lagere transportberoepen

4011 laders, lossers, vul- en inpak(machine)bedienden

41 MARITIEME E.A. WATERWEGTRANSPORTBEROEPEN

411 lagere maritieme e.a. waterwegtransportberoepen

4111 vissers, vis- en schaaldierkwekers, jagers e.d.

4112 matrozen e.a. scheepsdek- en machinekamerpersoneel

412 middelbare maritieme e.a. waterwegtransportberoepen

4121 scheepsofficieren, loodsen, walinspecteurs

42 RAIL- EN WEGTRANSPORTBEROEPEN

421 lagere rail- en wegtransportberoepen

4211 conducteurs, chauffeurs e.a. transportmiddelenbestuurders

43 LUCHT- EN OVERIGE TRANSPORTBEROEPEN

432 middelbare lucht- en overige transportberoepen

4321 vliegers, boordwerktuigkundigen, transportdienstleiders

50 MEDISCHE EN PARAMEDISCHE BEROEPEN

502 middelbare medische en paramedische beroepen

5021 gediplomeerde verpleegkundigen, verloskundigen

5022 leerling-verpleegkundigen, zieken- en kraamverzorgenden

5023 dokters-, tandarts- en dierenartsassistenten

5024 apothekersassistenten, opticiens, orthoptisten

5025 EEG-laboranten, keurmeesters, diëtisten, logopedisten, pedicuren e.d.

503 hogere medische en paramedische beroepen

5031 fysio-, arbeids- e.a. bewegingstherapeuten

5032 radiologische, medische en biologische laboranten

5033 geneeskundigen, medische adviseurs, apothekers

5034 diergeneeskundigen, veterinaire geneeskundigen

5035 tandheelkundigen en tandheelkundige specialisten 


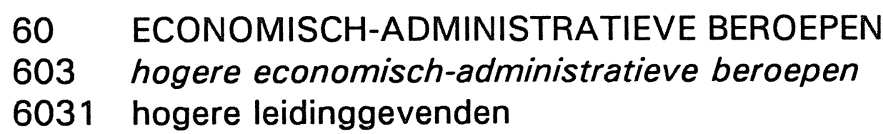

61 ADMINISTRATIEVE BEROEPEN

611 lagere administratieve beroepen

6111 postdistributiepersoneel

6112 datatypisten, computeroperators

612 middelbare administratieve beroepen

6121 administratief leidinggevenden

6122 secretaressen, typisten

6123 bibliotheekassistenten

6124 boekhoudkundige, belasting-, loket- en bankemployees

6125 commercieel-administratieve employees

6126 telefonisten, balie-employees, enquêteurs e.d.

613 hogere administratieve beroepen

6131 systeemanalisten, -programmeurs en -beheerders

6132 accountants, economen e.a. economische specialisten

62 COMMERCIËLE BEROEPEN

621 lagere commerciële beroepen

6211 winkel-, straat- en marktverkopers, demonstrateurs

622 middelbare commerciële beroepen

6221 winkeliers e.a. detail- en groothandelaren

6222 in-/verkoopchefs, handels- en verzekeringsagenten, makelaars e.d.

63 BESTUURLIJKE EN JURIDISCHE BEROEPEN

633 hogere bestuurlijke en juridische beroepen

6331 leden en leidinggevenden openbaar bestuur, beleidsambtenaren

6332 juristen

70 SOCIAAL-CULTURELE BEROEPEN

702 middelbare sociaal-culturele beroepen

7021 auteurs, journalisten, nieuwslezers, presentatoren

703 hogere sociaal-culturele beroepen

7031 bibliothecarissen, archivarissen, conservatoren

7032 personeels- en beroepenspecialisten, arbeidsbemiddelaars

7033 maatschappelijk werkers, reclasseringsambtenaren

7034 sociale wetenschapsbeoefenaren

7035 overige sociaal-culturele en commerciële vakspecialisten

\section{VERZORGENDE EN DIENSTVERLENENDE BEROEPEN}

81 HORECABEROEPEN

811 lagere horecaberoepen

8111 koks, kelners e.a. keuken- en serveerpersoneel

812 middelbare horecaberoepen

8121 houders en leidinggevenden horeca- en recreatiebedrijven 
82 VERZORGENDE BEROEPEN

821 lagere verzorgende beroepen

8211 portiers, schoonmaak- e.a. lager dienstverlenend personeel

8212 kinder-, gezins-, bejaarden- e.a. verzorgend personeel

822 middelbare verzorgende beroepen

8221 kappers, schoonheidsspecialisten

OPENBARE ORDE- EN VEILIGHEIDSBEROEPEN

91 POLITIE-, BRANDWEER- EN BEWAKINGSBEROEPEN

912 middelbare politie-, brandweer- en bewakingsberoepen

9121 politie-, brandweer- en bewakingspersoneel

92 MILITAIRE BEROEPEN

922 middelbare militaire beroepen

9221 beroepsmilitairen 

$-48-$

BIJLAGE 2: KOPPELSCHEMA TUSSEN CBS- EN ROA-BEROEPENCODES

ROA-beroepsklasse

0131

0132

0133

0221

1131

1231

1321

1331

2011

2012

2031

3011

3012

3021

3022

3023

3024

3031

3111

3112

3211

3212

3213

3311

3312

3411

3511

3611

3612

3613

3614

3615

3621

3622

3631

3711

3712

3721

3722

3731

3811

3911

3912

3913
CBS-beroepsgroepen

133-135

131-132

139

180

195

141,149

162-163

$161,171-175,591$

$621-624,629,632$

$601-602,609,611-613,631,680$

053

979

$961,969,972-974$

024,028,211-214,701-702

461

032

014,036

011-013,026-027,029,051-052,081-082,085

$771-775,777,779,781-783$

776

$751-756,759,760$

$796,801-803$

$791-795,799$

$731-734,910$

$811-812,818-819,941-942,954,958$

$921-927,929$

$741-745,749$

$711-713,721-729$

$834-836,839,846,849$

$872,874,879-880$

$820,831-833,841,873$

$842,844-845$

843

$035,037,039,043$

025

$853,944,949$

857

851-852,854-856,859-860

034

023

$891-894,899,901-902,939,943$

951,955

952-953,956-957

931 
$-49-$

ROA-beroepsklasse

3914

3915

3921

3931

4011

4111

4112

4121

4211

4321

5021

5022

5023

5024

5025

5031

5032

5033

5034

5035

6031

6111

6112

6121

6122

6123

6124

6125

6126

6131

6132

6211

6221

6222

6331

6332

7021

7031

7032

7033

7034

7035

8111

8121

8211

8212

8221

9121

9221
CBS-beroepsgroepen

871

959,991-993,998-999

033

021-022,031

971

641,649

981-982

042

$351,360,983-986,989$

359,041

071,073

072,074

593

068,075

$064,069,079$

076

054,077

061,067

065

063

219

370

$322,341-342$

300

321

395

331,339

391-393

$380,394,399$

083-084

090,110

$481-482,490$

$352,401-402,411-412,421-422,431-439$

$451-452,462,471-473$

201-202,310

$121-122,129$

$151,159,179$

191

194

193

192

199

$531-532$

501-502,511-514,518-519,520

$541,551-552,560,592,599$

542

570

$581-582,589$

660 


\section{BIJLAGE 3: AANTAL WERKZAME PERSONEN IN 1985 NAAR GESLACHT EN CBS- EN ROA-BEROEPSKLASSEN}

Aantal werkzame personen volgens AKT 1985 naar CBS-BEROEPSKLASSEN en geslacht

\begin{tabular}{|c|c|}
\hline CBS-code & mannen \\
\hline 01 & 27100 \\
\hline $02 / 03$ & 174500 \\
\hline 04 & 16600 \\
\hline 05 & 16900 \\
\hline 06/07 & 75000 \\
\hline 08 & 47300 \\
\hline 09 & 13500 \\
\hline 11 & 11700 \\
\hline 12 & 14400 \\
\hline 13 & 152500 \\
\hline 14 & 9100 \\
\hline 15 & 13700 \\
\hline 16 & 20900 \\
\hline 17 & 10500 \\
\hline 18 & 5100 \\
\hline 19 & 58600 \\
\hline 20 & 2900 \\
\hline 21 & 154000 \\
\hline 30 & 14500 \\
\hline 31 & 15900 \\
\hline 32 & 6800 \\
\hline 33 & 161800 \\
\hline 34 & 7600 \\
\hline 35 & 26100 \\
\hline 36 & 1900 \\
\hline 37 & 34700 \\
\hline 38 & 3200 \\
\hline 39 & 188300 \\
\hline 40 & 28600 \\
\hline 41 & 14700 \\
\hline 42 & 20000 \\
\hline $43 / 44$ & 65600 \\
\hline 45 & 37700 \\
\hline 46 & 48200 \\
\hline 47 & 29400 \\
\hline 48 & 68000 \\
\hline 49 & 230 \\
\hline 50 & 8600 \\
\hline 51 & 23800 \\
\hline 52 & 4700 \\
\hline 53 & 42900 \\
\hline 54 & 8100 \\
\hline 55 & 35700 \\
\hline 56 & 2800 \\
\hline 57 & 7200 \\
\hline 58 & 52800 \\
\hline 59 & 9300 \\
\hline 60 & 7500 \\
\hline
\end{tabular}

$\begin{array}{rr}\text { vrouwen } & \text { totaal } \\ & \\ 6500 & 33700 \\ 4200 & 178600 \\ 380 & 17000 \\ 12300 & 29300 \\ 191700 & 266700 \\ 3600 & 51000 \\ 1600 & 15100 \\ 810 & 12500 \\ 4100 & 18500 \\ 122600 & 275100 \\ 780 & 9900 \\ 6000 & 19700 \\ 8600 & 29500 \\ 6700 & 17100 \\ 5000 & 10100 \\ 50000 & 108600 \\ 1400 & 4300 \\ 10800 & 164700 \\ 2900 & 17500 \\ 450 & 16300 \\ 141700 & 148500 \\ 130100 & 291900 \\ 3800 & 11400 \\ 1200 & 27400 \\ 160 & 2100 \\ 9200 & 44000 \\ 14600 & 17800 \\ 191500 & 379800 \\ 1600 & 30200 \\ 1900 & 16600 \\ 1600 & 21700 \\ 16000 & 81600 \\ 6900 & 44600 \\ 2300 & 50600 \\ 5200 & 34600 \\ 163500 & 231600 \\ 140 & 370 \\ 4500 & 13100 \\ 6300 & 30100 \\ 5800 & 10400 \\ 65300 & 180600 \\ 172500 & 137200 \\ 101400 & 9900 \\ 7100 & \\ 23600 & 2900 \\ 19500 & \end{array}$


$-51-$

\begin{tabular}{|c|c|c|c|}
\hline CBS-code & mannen & vrouwen & totaal \\
\hline 61 & 124600 & 4600 & 129200 \\
\hline 62 & 84600 & 46000 & 130600 \\
\hline 63 & 3800 & 40 & 3900 \\
\hline 64 & 3400 & 110 & 3600 \\
\hline 70 & 96500 & 4100 & 100600 \\
\hline 71 & 1800 & 0 & 1800 \\
\hline 72 & 13000 & 290 & 13300 \\
\hline 73 & 7000 & 170 & 7200 \\
\hline 74 & 22500 & 1800 & 24300 \\
\hline 75 & 10200 & 1300 & 11500 \\
\hline 76 & 1000 & 0 & 1000 \\
\hline 77 & 55700 & 4600 & 60400 \\
\hline 78 & 1700 & 410 & 2100 \\
\hline 79 & 11100 & 21400 & 32500 \\
\hline 80 & 5300 & 2500 & 7900 \\
\hline 81 & 16600 & 210 & 16800 \\
\hline 82 & 840 & 0 & 840 \\
\hline 83 & 39600 & 890 & 40500 \\
\hline 84 & 152300 & 3400 & 155700 \\
\hline 85 & 103100 & 7000 & 110100 \\
\hline 86 & 1900 & 160 & 2000 \\
\hline 87 & 103800 & 910 & 104800 \\
\hline 88 & 1500 & 630 & 2200 \\
\hline 89 & 8100 & 1200 & 9300 \\
\hline 90 & 12000 & 1800 & 13800 \\
\hline 91 & 4900 & 640 & 5600 \\
\hline 92 & 37500 & 5900 & 43400 \\
\hline 93 & 38900 & 460 & 39300 \\
\hline 94 & 9700 & 3100 & 12900 \\
\hline 95 & 168600 & 590 & 169200 \\
\hline 96 & 6200 & 50 & 6200 \\
\hline 97 & 129500 & 30500 & 160000 \\
\hline 98 & 143200 & 4700 & 147900 \\
\hline 99 & 43000 & 2300 & 45400 \\
\hline BM & 39200 & 600 & 39800 \\
\hline
\end{tabular}

BM: Beroepsmilitairen

aantallen boven de 1000: afgerond op 100-tallen; aantallen onder de 1000: afgerond op 10-tallen. 
$-52-$

Aantal werkzame personen volgens AKT 1985 naar ROA-BEROEPSKLASSEN en geslacht

\begin{tabular}{|c|c|c|c|}
\hline ROA-code & mannen & vrouwen & totaal \\
\hline 0131 & 37900 & 63700 & 101600 \\
\hline 0132 & 93200 & 51600 & 144800 \\
\hline 0133 & 21400 & 7200 & 28600 \\
\hline 0221 & 5100 & 5000 & 10100 \\
\hline 1131 & 1400 & 2200 & 3600 \\
\hline 1231 & 9100 & 780 & 9900 \\
\hline 1321 & 17000 & 6100 & 23100 \\
\hline 1331 & 14400 & 9200 & 23500 \\
\hline 2011 & 87500 & 46100 & 133500 \\
\hline 2012 & 133100 & 4700 & 137800 \\
\hline 2031 & 3300 & 170 & 3500 \\
\hline 3011 & 18500 & 90 & 18500 \\
\hline 3012 & 27400 & 350 & 27700 \\
\hline 3021 & 230700 & 11200 & 241900 \\
\hline 3022 & 10200 & 410 & 10600 \\
\hline 3023 & 27400 & 1100 & 28500 \\
\hline 3024 & 23900 & 6200 & 30200 \\
\hline 3031 & 28900 & 2400 & 31300 \\
\hline 3111 & 38100 & 4000 & 42100 \\
\hline 3112 & 19300 & 1100 & 20400 \\
\hline 3211 & 11300 & 1300 & 12600 \\
\hline 3212 & 12900 & 5100 & 18000 \\
\hline 3213 & 3600 & 18900 & 22500 \\
\hline 3311 & 12000 & 810 & 12800 \\
\hline 3312 & 102400 & 660 & 103100 \\
\hline 3411 & 37500 & 5900 & 43400 \\
\hline 3511 & 22500 & 1800 & 24300 \\
\hline 3611 & 14800 & 290 & 15100 \\
\hline 3612 & 33100 & 2200 & 35200 \\
\hline 3613 & 50700 & 1300 & 52000 \\
\hline 3614 & 69500 & 720 & 70300 \\
\hline 3615 & 63700 & 1200 & 64800 \\
\hline 3621 & 39900 & 220 & 40100 \\
\hline 3622 & 24100 & 250 & 24300 \\
\hline 3631 & 12700 & 0 & 12700 \\
\hline 3711 & 15200 & 7900 & 23200 \\
\hline 3712 & 5500 & 60 & 5600 \\
\hline 3721 & 89300 & 2000 & 91300 \\
\hline 3722 & 12300 & 40 & 12300 \\
\hline 3731 & 8300 & 0 & 8300 \\
\hline 3811 & 34100 & 3400 & 37500 \\
\hline 3911 & 41800 & 220 & 42100 \\
\hline 3912 & 21900 & 30 & 21900 \\
\hline 3913 & 28600 & 250 & 28800 \\
\hline 3914 & 41300 & 180 & 41500 \\
\hline 3915 & 63100 & 2300 & 65400 \\
\hline 3921 & 24200 & 410 & 24600 \\
\hline 3931 & 20600 & 570 & 21200 \\
\hline 4011 & 89800 & 30200 & 120000 \\
\hline 4111 & 3400 & 110 & 3600 \\
\hline 4112 & 6800 & 300 & 7100 \\
\hline 4121 & 10800 & 210 & 11000 \\
\hline
\end{tabular}


$-53-$

\begin{tabular}{|c|c|c|c|}
\hline ROA-code & mannen & vrouwen & totaal \\
\hline 4211 & 138600 & 4500 & 143100 \\
\hline 4321 & 27300 & 860 & 28200 \\
\hline 5021 & 17900 & 65400 & 83300 \\
\hline 5022 & 12300 & 74000 & 86300 \\
\hline 5023 & 180 & 16700 & 16900 \\
\hline 5024 & 2300 & 10200 & 12500 \\
\hline 5025 & 6100 & 14800 & 20900 \\
\hline 5031 & 9500 & 15700 & 25200 \\
\hline 5032 & 10600 & 15300 & 25900 \\
\hline 5033 & 19700 & 6200 & 26000 \\
\hline 5034 & 2000 & 240 & 2200 \\
\hline 5035 & 3900 & 880 & 4800 \\
\hline 6031 & 49600 & 4700 & 54300 \\
\hline 6111 & 34700 & 9200 & 44000 \\
\hline 6112 & 9100 & 20500 & 29700 \\
\hline 6121 & 14500 & 2900 & 17500 \\
\hline 6122 & 5300 & 124900 & 130300 \\
\hline 6123 & 9600 & 11300 & 20800 \\
\hline 6124 & 161800 & 130100 & 291900 \\
\hline 6125 & 165300 & 141200 & 306500 \\
\hline 6126 & 16700 & 53600 & 70300 \\
\hline 6131 & 44700 & 3400 & 48200 \\
\hline 6132 & 25200 & 2400 & 27600 \\
\hline 6211 & 68300 & 163600 & 231900 \\
\hline 6221 & 109600 & 20000 & 129600 \\
\hline 6222 & 105100 & 14100 & 119100 \\
\hline 6331 & 18800 & 1900 & 20700 \\
\hline 6332 & 14400 & 4100 & 18500 \\
\hline 7021 & 13900 & 6100 & 20000 \\
\hline 7031 & 6200 & 6500 & 12700 \\
\hline 7032 & 7700 & 3300 & 11000 \\
\hline 7033 & 22000 & 26300 & 48400 \\
\hline 7034 & 14400 & 9400 & 23800 \\
\hline 7035 & 7000 & 2200 & 9200 \\
\hline 8111 & 42900 & 65300 & 108100 \\
\hline 8121 & 37000 & 16600 & 53600 \\
\hline 8211 & 52400 & 152200 & 204600 \\
\hline 8212 & 3200 & 131400 & 134700 \\
\hline 8221 & 7200 & 23600 & 30800 \\
\hline 9121 & 52800 & 2900 & 55700 \\
\hline 9221 & 39200 & 600 & 39800 \\
\hline
\end{tabular}

aantallen boven de 1000: afgerond op 100-tallen; aantallen onder de 1000: afgerond op 10-tallen. 
BIJLAGE 4: AANTAL WERKZAME PERSONEN IN 1985 NAAR OPLEIDINGSNIVEAU EN CBS- EN ROA-BEROEPSKLASSEN

Procentuele verdeling van de werkzame personen volgens AKT 1985 naar CBS-BEROEPSKLASSEN en hoogst behaalde opleidingsniveau (SOI 1e digit)

\begin{tabular}{|c|c|c|c|c|c|}
\hline CBS-code & $\begin{array}{l}\text { BO } \\
\%\end{array}$ & $\begin{array}{l}\text { AVO-LT/LBO } \\
\%\end{array}$ & $\begin{array}{l}\text { AVO-HT/MBO } \\
\%\end{array}$ & $\begin{array}{l}\mathrm{HBO} \\
\%\end{array}$ & $\begin{array}{r}\text { WO } \\
\%\end{array}$ \\
\hline 01 & 4 & 12 & 34 & 33 & 15 \\
\hline $02 / 03$ & 1 & 7 & 45 & 33 & 14 \\
\hline 04 & 13 & 8 & 30 & 47 & 1 \\
\hline 05 & 1 & 6 & 22 & 48 & 23 \\
\hline 06/07 & 1 & 6 & 59 & 21 & 12 \\
\hline 08 & 1 & 6 & 41 & 38 & 15 \\
\hline 09 & 1 & 3 & 28 & 34 & 35 \\
\hline 11 & 0 & 5 & 28 & 28 & 38 \\
\hline 12 & 0 & 1 & 9 & 9 & 81 \\
\hline 13 & 0 & 1 & 9 & 71 & 19 \\
\hline 14 & 0 & 1 & 6 & 32 & 59 \\
\hline 15 & 1 & 8 & 45 & 35 & 11 \\
\hline 16 & 6 & 16 & 37 & 37 & 2 \\
\hline 17 & 2 & 10 & 22 & 63 & 3 \\
\hline 18 & 4 & 37 & 38 & 18 & 1 \\
\hline 19 & 1 & 3 & 20 & 47 & 29 \\
\hline 20 & 1 & 9 & 25 & 26 & 36 \\
\hline 21 & 5 & 12 & 46 & 25 & 12 \\
\hline 30 & 3 & 19 & 61 & 15 & 2 \\
\hline 31 & 0 & 6 & 31 & 34 & 29 \\
\hline 32 & 3 & 29 & 48 & 18 & 1 \\
\hline 33 & 5 & 30 & 56 & 8 & 1 \\
\hline 34 & 8 & 36 & 49 & 5 & 0 \\
\hline 35 & 19 & 30 & 44 & 7 & 0 \\
\hline 36 & 21 & 37 & 41 & 2 & 0 \\
\hline 37 & 27 & 49 & 21 & 1 & 0 \\
\hline 38 & 11 & 42 & 39 & 6 & 0 \\
\hline 39 & 7 & 32 & 51 & 8 & 1 \\
\hline 40 & 6 & 16 & 55 & 17 & 6 \\
\hline 41 & 5 & 16 & 70 & 8 & 1 \\
\hline 42 & 21 & 24 & 45 & 8 & 2 \\
\hline $43 / 44$ & 11 & 16 & 68 & 3 & 0 \\
\hline 45 & 7 & 23 & 60 & 9 & 0 \\
\hline 46 & 6 & 21 & 56 & 15 & 1 \\
\hline 47 & 3 & 12 & 67 & 16 & 2 \\
\hline 48 & 17 & 47 & 34 & 2 & 0 \\
\hline 49 & 13 & 36 & 34 & 17 & 0 \\
\hline 50 & 19 & 32 & 39 & 8 & 0 \\
\hline 51 & 19 & 25 & 48 & 4 & 0 \\
\hline 52 & 11 & 17 & 52 & 19 & 0 \\
\hline 53 & 25 & 50 & 21 & 1 & 0 \\
\hline 54 & 21 & 35 & 40 & 3 & 0 \\
\hline 55 & 44 & 41 & 13 & 0 & 0 \\
\hline 56 & 42 & 40 & 16 & 1 & 0 \\
\hline 57 & 3 & 9 & 87 & 0 & 0 \\
\hline
\end{tabular}


$-55-$

\begin{tabular}{|c|c|c|c|c|c|}
\hline CBS-code & $\mathrm{BO}$ & AVO-LT/LBO & AVO-HT/MBO & $\mathrm{HBO}$ & wo \\
\hline 58 & 6 & 18 & 73 & 2 & 0 \\
\hline 59 & 14 & 26 & 52 & 6 & 2 \\
\hline 60 & 9 & 24 & 52 & 12 & 2 \\
\hline 61 & 15 & 44 & 38 & 1 & 0 \\
\hline 62 & 27 & 45 & 26 & 1 & 0 \\
\hline 63 & 27 & 46 & 27 & 0 & 0 \\
\hline 64 & 35 & 41 & 24 & 0 & 0 \\
\hline 70 & 11 & 23 & 56 & 8 & 1 \\
\hline 71 & 25 & 43 & 30 & 2 & 0 \\
\hline 72 & 43 & 39 & 13 & 0 & 0 \\
\hline 73 & 46 & 35 & 14 & 1 & 0 \\
\hline 74 & 22 & 32 & 41 & 2 & 0 \\
\hline 75 & 55 & 32 & 12 & 1 & 0 \\
\hline 76 & 61 & 39 & 0 & 0 & 0 \\
\hline 77 & 28 & 37 & 32 & 1 & 0 \\
\hline 78 & 39 & 44 & 16 & 1 & 0 \\
\hline 79 & 27 & 46 & 25 & 1 & 0 \\
\hline 80 & 36 & 38 & 25 & 0 & 0 \\
\hline 81 & 29 & 41 & 29 & 1 & 0 \\
\hline 82 & 28 & 49 & 23 & 0 & 0 \\
\hline 83 & 24 & 41 & 32 & 0 & 0 \\
\hline 84 & 14 & 39 & 46 & 1 & 0 \\
\hline 85 & 11 & 29 & 55 & 3 & 0 \\
\hline 86 & 6 & 28 & 59 & 4 & 0 \\
\hline 87 & 17 & 49 & 33 & 0 & 0 \\
\hline 88 & 6 & 26 & 66 & 2 & 0 \\
\hline 89 & 40 & 37 & 21 & 1 & 0 \\
\hline 90 & 38 & 45 & 15 & 0 & 0 \\
\hline 91 & 48 & 36 & 13 & 0 & 0 \\
\hline 92 & 18 & 37 & 42 & 2 & 1 \\
\hline 93 & 25 & 41 & 33 & 0 & 0 \\
\hline 94 & 38 & 36 & 23 & 1 & 0 \\
\hline 95 & 23 & 46 & 29 & 1 & 0 \\
\hline 96 & 15 & 28 & 48 & 8 & 0 \\
\hline 97 & 42 & 40 & 16 & 1 & 0 \\
\hline 98 & 31 & 44 & 23 & 1 & 0 \\
\hline 99 & 55 & 31 & 11 & 0 & 0 \\
\hline $\mathrm{BM}$ & 5 & 27 & 54 & 12 & 2 \\
\hline
\end{tabular}

BM: Beroepsmilitairen 
$-56-$

Procentuele verdeling van de werkzame personen volgens AKT 1985 naar ROA-BEROEPSKLASSEN en hoogst behaalde opleidingsniveau (SOI 1e digit)

\begin{tabular}{|c|c|c|c|c|c|}
\hline ROA-code & $\begin{array}{l}\text { BO } \\
\%\end{array}$ & $\begin{array}{c}\text { AVO-LT/LBO } \\
\%\end{array}$ & $\begin{array}{c}\text { AVO-HT/MBO } \\
\%\end{array}$ & $\begin{array}{c}\mathrm{HBO} \\
\%\end{array}$ & $\begin{array}{r}\text { Wo } \\
\%\end{array}$ \\
\hline 0131 & 0 & 0 & 12 & 87 & 1 \\
\hline 0132 & 0 & 1 & 5 & 63 & 30 \\
\hline 0133 & 0 & 4 & 19 & 51 & 25 \\
\hline 0221 & 4 & 37 & 38 & 18 & 1 \\
\hline 1131 & 3 & 5 & 18 & 34 & 40 \\
\hline 1231 & 0 & 1 & 6 & 32 & 59 \\
\hline 1321 & 6 & 18 & 41 & 31 & 2 \\
\hline 1331 & 3 & 10 & 21 & 61 & 3 \\
\hline 2011 & 27 & 45 & 26 & 1 & 0 \\
\hline 2012 & 15 & 43 & 39 & 2 & 0 \\
\hline 2031 & 0 & 0 & 4 & 57 & 40 \\
\hline 3011 & 50 & 36 & 13 & 0 & 0 \\
\hline 3012 & 32 & 30 & 34 & 3 & 0 \\
\hline 3021 & 8 & 17 & 52 & 16 & 6 \\
\hline 3022 & 2 & 7 & 47 & 41 & 3 \\
\hline 3023 & 1 & 15 & 66 & 16 & 2 \\
\hline 3024 & 5 & 13 & 40 & 39 & 1 \\
\hline 3031 & 0 & 2 & 8 & 27 & 62 \\
\hline 3111 & 35 & 38 & 25 & 1 & 0 \\
\hline 3112 & 17 & 36 & 45 & 1 & 0 \\
\hline 3211 & 55 & 32 & 11 & 1 & 0 \\
\hline 3212 & 34 & 38 & 26 & 1 & 0 \\
\hline 3213 & 24 & 49 & 25 & 1 & 0 \\
\hline 3311 & 47 & 35 & 14 & 0 & 0 \\
\hline 3312 & 14 & 46 & 38 & 1 & 0 \\
\hline 3411 & 18 & 37 & 42 & 2 & 1 \\
\hline 3511 & 22 & 32 & 41 & 2 & 0 \\
\hline 3611 & 41 & 40 & 15 & 1 & 0 \\
\hline 3612 & 33 & 42 & 22 & 1 & 0 \\
\hline 3613 & 18 & 50 & 29 & 0 & 0 \\
\hline 3614 & 14 & 42 & 43 & 0 & 0 \\
\hline 3615 & 13 & 38 & 48 & 1 & 0 \\
\hline 3621 & 8 & 39 & 51 & 0 & 0 \\
\hline 3622 & 1 & 8 & 58 & 30 & 2 \\
\hline 3631 & 0 & 3 & 18 & 55 & 23 \\
\hline 3711 & 34 & 41 & 23 & 1 & 0 \\
\hline 3712 & 17 & 47 & 35 & 1 & 0 \\
\hline 3721 & 7 & 26 & 62 & 4 & 0 \\
\hline 3722 & 0 & 3 & 63 & 31 & 1 \\
\hline 3731 & 0 & 1 & 13 & 60 & 26 \\
\hline 3811 & 39 & 40 & 19 & 0 & 0 \\
\hline 3911 & 34 & 45 & 20 & 0 & 0 \\
\hline 3912 & 36 & 47 & 15 & 1 & 0 \\
\hline 3913 & 21 & 41 & 36 & 0 & 0 \\
\hline 3914 & 14 & 46 & 39 & 0 & 0 \\
\hline 3915 & 51 & 33 & 14 & 0 & 0 \\
\hline 3921 & 2 & 8 & 69 & 19 & 1 \\
\hline 3931 & 0 & 1 & 11 & 57 & 31 \\
\hline 4011 & 41 & 42 & 14 & 1 & 0 \\
\hline 4111 & 35 & 41 & 24 & 0 & 0 \\
\hline
\end{tabular}


$-57-$

\begin{tabular}{|c|c|c|c|c|c|}
\hline ROA-code & $\mathrm{BO}$ & AVO-LT/LBO & AVO-HT/MBO & $\mathrm{HBO}$ & wo \\
\hline 4112 & 26 & 35 & 33 & 4 & 0 \\
\hline 4121 & 18 & 10 & 35 & 34 & 1 \\
\hline 4211 & 31 & 44 & 23 & 0 & 0 \\
\hline 4321 & 18 & 27 & 41 & 13 & 0 \\
\hline 5021 & 0 & 0 & 75 & 25 & 0 \\
\hline 5022 & 2 & 14 & 78 & 6 & 0 \\
\hline 5023 & 4 & 15 & 71 & 8 & 2 \\
\hline 5024 & 1 & 3 & 95 & 1 & 0 \\
\hline 5025 & 1 & 15 & 43 & 38 & 3 \\
\hline 5031 & 1 & 3 & 27 & 69 & 1 \\
\hline 5032 & 1 & 6 & 29 & 62 & 2 \\
\hline 5033 & 0 & 0 & 1 & 2 & 97 \\
\hline 5034 & 0 & 0 & 0 & 0 & 100 \\
\hline 5035 & 0 & 0 & 0 & 1 & 99 \\
\hline 6031 & 1 & 6 & 40 & 36 & 17 \\
\hline 6111 & 27 & 49 & 21 & 1 & 0 \\
\hline 6112 & 10 & 50 & 36 & 3 & 0 \\
\hline 6121 & 3 & 19 & 61 & 15 & 2 \\
\hline 6122 & 2 & 25 & 51 & 21 & 1 \\
\hline 6123 & 5 & 31 & 51 & 12 & 1 \\
\hline 6124 & 5 & 30 & 56 & 8 & 1 \\
\hline 6125 & 7 & 32 & 51 & 8 & 2 \\
\hline 6126 & 8 & 32 & 49 & 9 & 1 \\
\hline 6131 & 1 & 6 & 42 & 39 & 12 \\
\hline 6132 & 1 & 4 & 28 & 31 & 36 \\
\hline 6211 & 17 & 47 & 34 & 2 & 0 \\
\hline 6221 & 9 & 16 & 65 & 6 & 2 \\
\hline 6222 & 6 & 20 & 62 & 11 & 1 \\
\hline 6331 & 0 & 6 & 30 & 33 & 30 \\
\hline 6332 & 0 & 1 & 9 & 9 & 81 \\
\hline 7021 & 1 & 8 & 45 & 35 & 11 \\
\hline 7031 & 1 & 2 & 25 & 56 & 16 \\
\hline 7032 & 0 & 4 & 33 & 57 & 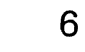 \\
\hline 7033 & 1 & 3 & 21 & 64 & 11 \\
\hline 7034 & 0 & 2 & 11 & 18 & 69 \\
\hline 7035 & 1 & 3 & 22 & 17 & 57 \\
\hline 8111 & 25 & 50 & 21 & 1 & 0 \\
\hline 8121 & 17 & 25 & 47 & 8 & 0 \\
\hline 8211 & 40 & 42 & 16 & 1 & 0 \\
\hline 8212 & 18 & 32 & 46 & 3 & 0 \\
\hline 8221 & 3 & 9 & 87 & 0 & \\
\hline 9121 & 6 & 18 & 73 & 2 & \\
\hline 9221 & 5 & 27 & 54 & 12 & \\
\hline
\end{tabular}


$-58-$

BIJLAGE 5: GINI-HIRSCHMAN-COËFFICIËNTEN VOOR DE OPLEIDINGENSPREIDING NAAR CBS- EN ROA-BEROEPSKLASSEN

\begin{tabular}{|c|c|}
\hline CBS-code & Opleidingenspreiding \\
\hline 01 & 0.88 \\
\hline $02 / 03$ & 0.78 \\
\hline 04 & 0.73 \\
\hline 05 & 0.89 \\
\hline $06 / 07$ & 0.89 \\
\hline 08 & 0.89 \\
\hline 09 & 0.87 \\
\hline 11 & 0.83 \\
\hline 12 & 0.36 \\
\hline 13 & 0.56 \\
\hline 14 & 0.59 \\
\hline 15 & 0.92 \\
\hline 16 & 0.86 \\
\hline 17 & 0.73 \\
\hline 18 & 0.89 \\
\hline 19 & 0.83 \\
\hline 20 & 0.94 \\
\hline 21 & 0.93 \\
\hline 30 & 0.88 \\
\hline 31 & 0.91 \\
\hline 32 & 0.85 \\
\hline 33 & 0.85 \\
\hline 34 & 0.85 \\
\hline 35 & 0.90 \\
\hline 36 & 0.88 \\
\hline 37 & 0.87 \\
\hline 38 & 0.89 \\
\hline 39 & 0.90 \\
\hline 40 & 0.88 \\
\hline 41 & 0.72 \\
\hline 42 & 0.87 \\
\hline $43 / 44$ & 0.73 \\
\hline 45 & 0.83 \\
\hline 46 & 0.87 \\
\hline 47 & 0.72 \\
\hline 48 & 0.89 \\
\hline 49 & 0.86 \\
\hline 50 & 0.90 \\
\hline 51 & 0.87 \\
\hline 52 & 0.93 \\
\hline 53 & 0.83 \\
\hline 54 & 0.85 \\
\hline 55 & 0.75 \\
\hline 56 & 0.76 \\
\hline 57 & 0.66 \\
\hline 58 & 0.62 \\
\hline 59 & 0.88 \\
\hline
\end{tabular}




\section{CBS-code Opleidingenspreiding}

$\begin{array}{ll}60 & 0.76 \\ 61 & 0.74 \\ 62 & 0.86 \\ 63 & 0.77 \\ 64 & 0.80 \\ 70 & 0.76 \\ 71 & 0.83 \\ 72 & 0.71 \\ 73 & 0.71 \\ 74 & 0.84 \\ 75 & 0.66 \\ 76 & 0.53 \\ 77 & 0.81 \\ 78 & 0.78 \\ 79 & 0.83 \\ 80 & 0.80 \\ 81 & 0.75 \\ 82 & 0.73 \\ 83 & 0.73 \\ 84 & 0.71 \\ 85 & 0.68 \\ 86 & 0.85 \\ 87 & 0.69 \\ 88 & 0.69 \\ 89 & 0.78 \\ 90 & 0.78 \\ 91 & 0.70 \\ 92 & 0.81 \\ 93 & 0.73 \\ 94 & 0.80 \\ 95 & 0.72 \\ 96 & 0.81 \\ 97 & 0.78 \\ 98 & 0.84 \\ 99 & 0.64 \\ \text { BM } & 0.83\end{array}$

BM: Beroepsmilitairen 
$-60-$

Gini-Hirschman-coëfficiënten voor de opleidingenspreiding naar ROA-BEROEPSKLASSEN

ROA-code Opleidingenspreiding

$\begin{array}{ll}0131 & 0.24 \\ 0132 & 0.66 \\ 0133 & 0.86 \\ 0221 & 0.89 \\ 1131 & 0.81 \\ 1231 & 0.59 \\ 1321 & 0.87 \\ 1331 & 0.73 \\ 2011 & 0.86 \\ 2012 & 0.74 \\ 2031 & 0.54 \\ 3011 & 0.70 \\ 3012 & 0.79 \\ 3021 & 0.86 \\ 3022 & 0.86 \\ 3023 & 0.62 \\ 3024 & 0.85 \\ 3031 & 0.83 \\ 3111 & 0.81 \\ 3112 & 0.77 \\ 3211 & 0.65 \\ 3212 & 0.80 \\ 3213 & 0.82 \\ 3311 & 0.71 \\ 3312 & 0.67 \\ 3411 & 0.81 \\ 3511 & 0.84 \\ 3611 & 0.73 \\ 3612 & 0.76 \\ 3613 & 0.70 \\ 3614 & 0.69 \\ 3615 & 0.71 \\ 3621 & 0.64 \\ 3622 & 0.74 \\ 3631 & 0.68 \\ 3711 & 0.82 \\ 3712 & 0.74 \\ 3721 & 0.61 \\ 3722 & 0.56 \\ 3731 & 0.64 \\ 3811 & 0.77 \\ 3911 & 0.71 \\ 3912 & 0.73 \\ 3913 & 0.72 \\ 3914 & 0.67 \\ 3915 & 0.68 \\ 3921 & 0.58 \\ 3931 & 0.79 \\ 4011 & \end{array}$




$\begin{array}{lc}\text { ROA-code } & \text { Opleidingenspreiding } \\ 4121 & 0.75 \\ 4211 & 0.84 \\ 4321 & 0.91 \\ 5021 & 0.54 \\ 5022 & 0.85 \\ 5023 & 0.74 \\ 5024 & 0.24 \\ 5025 & 0.89 \\ 5031 & 0.62 \\ 5032 & 0.77 \\ 5033 & 0.14 \\ 5034 & 0.04 \\ 5035 & 0.01 \\ 6031 & 0.93 \\ 6111 & 0.87 \\ 6112 & 0.86 \\ 6121 & 0.88 \\ 6122 & 0.84 \\ 6123 & 0.92 \\ 6124 & 0.85 \\ 6125 & 0.90 \\ 6126 & 0.90 \\ 6131 & 0.88 \\ 6132 & 0.87 \\ 6211 & 0.89 \\ 6221 & 0.78 \\ 6222 & 0.81 \\ 6331 & 0.93 \\ 6332 & 0.36 \\ 7021 & 0.92 \\ 7031 & 0.79 \\ 7032 & 0.80 \\ 7033 & 0.68 \\ 7034 & 0.67 \\ 7035 & 0.93 \\ 8111 & 0.83 \\ 8121 & 0.90 \\ 8211 & 0.79 \\ 8212 & 0.84 \\ 8221 & 0.66 \\ 9121 & 0.62 \\ 9221 & 0.83 \\ & \end{array}$


$-62-$

BIJLAGE 6: HETEROGENE CBS-BEROEPSKLASSEN MET BIJBEHORENDE ROABEROEPSKLASSEN EN ONDERLIGGENDE CBS-BEROEPSGROEPEN

$\begin{array}{cc}\text { CBS-code } & \text { ROA-co } \\ 06 / 07 & \\ 073 & 5021 \\ 071 & 5021 \\ 074 & 5022 \\ 072 & 5022 \\ 593 & 5023 \\ 075 & 5024 \\ 068 & 5024 \\ 064 & 5025 \\ 079 & 5025 \\ 069 & 5025 \\ 076 & 5031 \\ 054 & 5032 \\ 077 & 5032 \\ 061 & 5033 \\ 067 & 5033 \\ 065 & 5034 \\ 063 & 5035\end{array}$

13

Leerkrachten:

$\begin{array}{ll}135 & 0131 \\ 134 & 0131 \\ 133 & 0131 \\ 132 & 0132 \\ 131 & 0132 \\ 139 & 0133\end{array}$

19

Sociaal-wetenschappelijke e.a. vakspecialisten:

$\begin{array}{ll}195 & 1131 \\ 191 & 7031 \\ 194 & 7032 \\ 193 & 7033 \\ 192 & 7034 \\ 199 & 7035\end{array}$

39

Overige administratieve functies:

$395 \quad 6123$

$393 \quad 6125$

$392 \quad 6125$

$391 \quad 6125$

$399 \quad 6126$

$394 \quad 6126$

$380 \quad 6126$ 



\section{BIJLAGE 7: ROA-BEDRIJFSSECTOREN}

$\begin{aligned} \text { ROA-code } & \text { Naam } \\ 1 & \text { Landbouw en visserij } \\ 2 & \text { Voedings- en genotmiddelenindustrie } \\ 3 & \text { Textiel- en kledingindustrie } \\ 4 & \text { Hout- en bouwmaterialenindustrie } \\ 5 & \text { Papier- en grafische industrie } \\ 6 & \text { Chemische en rubberindustrie } \\ 7 & \text { Basismetaalindustrie } \\ 8 & \text { Metaalprodukten- en instrumentenindustrie } \\ 9 & \text { Elektrotechnische industrie } \\ 10 & \text { Transportmiddelenindustrie } \\ 11 & \text { Delfstoffenindustrie } \\ 12 & \text { Openbare nutsbedrijven } \\ 13 & \text { Bouw } \\ 14 & \text { Handel } \\ 15 & \text { Zee- en luchtvaart } \\ 16 & \text { Overig vervoer en communicatie } \\ 17 & \text { Banken en verzekeringen } \\ 18 & \text { Andere tertiaire diensten } \\ 19 & \text { Medische en veterinaire diensten } \\ 20 & \text { Andere kwartaire diensten } \\ 21 & \text { Overheid }\end{aligned}$

SBI-2-digit

$01,02,03$

20,21

$22,23,24$

25,32

26,27

$28,29,30,31$

33

$34,35,38,39$

36

37

$11,12,19$

40

51,52

$61,62,65,66$

73,75

$71,72,74,76,77$

81,82

$67,68,83,84,85,98,99$

93

$91,94,95,96,97$

90,92 

$-64-$

\section{BIJLAGE 8: GINI-HIRSCHMAN-COËFFICIËNTEN VOOR DE BRANCHESPREIDING NAAR CBS- EN ROA-BEROEPSKLASSEN}

Gini-Hirschman-coëfficiënten voor de bedrijfssectorspreiding naar CBS-BEROEPSKLASSEN

$$
\text { CBS-code Branchespreiding }
$$

$\begin{array}{rl}01 & 0.8969 \\ 02 / 03 & 0.9265 \\ 04 & 0.5807 \\ 05 & 0.7424 \\ 06 / 07 & 0.3075 \\ 08 & 0.8965 \\ 09 & 0.8899 \\ 11 & 0.2593 \\ 12 & 0.6837 \\ 13 & 0.0939 \\ 14 & 0.1930 \\ 15 & 0.8431 \\ 16 & 0.8131 \\ 17 & 0.1855 \\ 18 & 0.1716 \\ 19 & 0.7226 \\ 20 & 0.1324 \\ 21 & 0.9566 \\ 30 & 0.8834 \\ 31 & 0.1012 \\ 32 & 0.9305 \\ 33 & 0.8858 \\ 34 & 0.9423 \\ 35 & 0.7766 \\ 36 & 0.0000 \\ 37 & 0.4859 \\ 38 & 0.8861 \\ 39 & 0.9156 \\ 40 & 0.0028 \\ 41 & 0.0150 \\ 42 & 0.0041 \\ 43 / 44 & 0.0000 \\ 45 & 0.5382 \\ 46 & 0.6319 \\ 47 & 0.6006 \\ 48 & 0.2802 \\ 49 & 0.6902 \\ 50 & 0.6572 \\ 51 & 0.0085 \\ 52 & 0.7550 \\ 53 & 0.6864 \\ 54 & 0.3763 \\ 55 & 0.7780 \\ 56 & 0.2599 \\ 57 & 0.1002 \\ 58 & 0.4407 \\ 59 & 0.6324\end{array}$


CBS-code Branchespreiding

\begin{tabular}{rl}
60 & 0.3063 \\
61 & 0.0024 \\
62 & 0.3090 \\
63 & 0.5484 \\
64 & 0.1481 \\
70 & 0.9389 \\
71 & 0.4787 \\
72 & 0.6043 \\
73 & 0.5224 \\
74 & 0.3450 \\
75 & 0.3780 \\
76 & 0.6614 \\
77 & 0.3395 \\
78 & 0.0000 \\
79 & 0.6945 \\
80 & 0.5462 \\
81 & 0.5151 \\
82 & 0.1505 \\
83 & 0.5820 \\
84 & 0.9101 \\
85 & 0.8860 \\
86 & 0.3753 \\
87 & 0.8018 \\
88 & 0.6241 \\
89 & 0.3696 \\
90 & 0.3441 \\
91 & 0.2033 \\
92 & 0.4946 \\
93 & 0.5953 \\
94 & 0.8410 \\
95 & 0.3473 \\
96 & 0.8777 \\
97 & 0.9318 \\
98 & 0.6794 \\
99 & 0.7470 \\
BM & 0.0102 \\
\hline & \\
\hline 5
\end{tabular}

BM: Beroepsmilitairen 
$-66-$

Gini-Hirschman-coëfficiënten voor de bedrijfssectorspreiding naar ROA-BEROEPSKLASSEN

ROA-code Branchespreiding

$\begin{array}{ll}0131 & 0.0068 \\ 0132 & 0.0009 \\ 0133 & 0.6543 \\ 0221 & 0.1716 \\ 1131 & 0.7270 \\ 1231 & 0.1930 \\ 1321 & 0.7602 \\ 1331 & 0.2246 \\ 2011 & 0.3170 \\ 2012 & 0.0236 \\ 2031 & 0.7196 \\ 3011 & 0.9503 \\ 3012 & 0.8221 \\ 3021 & 0.9495 \\ 3022 & 0.6773 \\ 3023 & 0.8908 \\ 3024 & 0.9013 \\ 3031 & 0.8760 \\ 3111 & 0.4171 \\ 3112 & 0.0859 \\ 3211 & 0.4213 \\ 3212 & 0.8031 \\ 3213 & 0.4974 \\ 3311 & 0.4039 \\ 3312 & 0.6163 \\ 3411 & 0.4946 \\ 3511 & 0.3450 \\ 3611 & 0.6934 \\ 3612 & 0.6663 \\ 3613 & 0.6591 \\ 3614 & 0.7260 \\ 3615 & 0.9617 \\ 3621 & 0.5245 \\ 3622 & 0.9462 \\ 3631 & 0.8730 \\ 3711 & 0.6765 \\ 3712 & 0.7055 \\ 3721 & 0.9059 \\ 3722 & 0.8840 \\ 3731 & 0.8679 \\ 3811 & 0.8115 \\ 3911 & 0.1029 \\ 3912 & 0.2260 \\ 3913 & 0.2977 \\ 3914 & 0.4870 \\ 3915 & 0.6679 \\ 3921 & 0.6919 \\ 3931 & 0.7225 \\ 4011 & 0.9027 \\ 4111 & 0.1481 \\ 4112 & 0.7654\end{array}$


ROA-code Branchespreiding

$\begin{array}{ll}4121 & 0.6819 \\ 4211 & 0.6553 \\ 4321 & 0.8061 \\ 5021 & 0.1230 \\ 5022 & 0.3357 \\ 5023 & 0.0696 \\ 5024 & 0.3731 \\ 5025 & 0.4211 \\ 5031 & 0.2289 \\ 5032 & 0.5343 \\ 5033 & 0.2238 \\ 5034 & 0.1286 \\ 5035 & 0.0405 \\ 6031 & 0.9711 \\ 6111 & 0.4859 \\ 6112 & 0.9289 \\ 6121 & 0.8834 \\ 6122 & 0.9280 \\ 6123 & 0.7779 \\ 6124 & 0.8858 \\ 6125 & 0.9145 \\ 6126 & 0.9239 \\ 6131 & 0.8936 \\ 6132 & 0.6944 \\ 6211 & 0.2826 \\ 6221 & 0.0202 \\ 6222 & 0.7635 \\ 6331 & 0.1078 \\ 6332 & 0.6837 \\ 7021 & 0.8448 \\ 7031 & 0.6396 \\ 7032 & 0.8841 \\ 7033 & 0.5216 \\ 7034 & 0.7285 \\ 7035 & 0.6921 \\ 8111 & 0.6864 \\ 8121 & 0.4670 \\ 8211 & 0.8142 \\ 8212 & 0.0926 \\ 8221 & 0.1002 \\ 9121 & 0.4407 \\ 9221 & 0.0102\end{array}$




\title{
BIJLAGE 9: ROA-OPLEIDINGSTYPEN
}

\author{
Code $\quad$ Code \\ ROA Omschrijving SOI
}

1 Basisonderwijs, Buitengewoon Lager Onderwijs

000111201

2 MAVO, LAVO, IVO, Buitengewoon Voortgezet Onderwijs, Middenschool, onderbouw HAVO \& VWO

3 Lagere Land-, Tuin- en Bosbouwschool, School voor Visserij en Scheepvaart, Hoefbeslag

321322323329

4 LTS (excl. Horeca), LHNO-Textiel, Centrum voor Vakopleidingen (CVV), ITO e.a.

Lager Technisch Onderwijs

331336338339

5 Lagere Vervoer- \& Havenopleidingen voor Bus-, Taxien Vrachtwagenchauffeur, Matroos, Visser, Maat, Machinist, Scheepskok en Postbode

341342343344349

6 Lagere Opleidingen voor Ziekenverzorger, Verpleegassistent, Kraamhulp en Dierenartsassistent

7 LEAO, LMO/LDS, LHNO-Kantoor/Verkoop e.a. Lagere Economisch-Administratieve en Commerciële Opleidingen

8 LHNO (excl. Kantoor/Verkoop/Textiel), Opleidingen voor Gezins-, Bejaarden- en Kinderverzorging, Lagere Horeca Opleidingen (o.a. LTS) e.d.

9 Lagere Beveiligings- en Bewakingsopleidingen

11 Bovenbouw HAVO, VWO, Atheneum, Gymnasium, VHBO

12 Auto-/Motorrij-instructeur, Praktijkdocenten Lichamelijke Oefening (CIOS), Kapper, Grafisch Bedrijf, Coupeuse, Handelscorrespondentie e.d.

351352354359

361362364366

381383384386 391392393394 401

406

13 Middelbare Land-, Tuin-, Bosbouw- en Cultuurtechnische school (excl.levensmiddelentechniek), KMBO/LLW Agrarisch, Milieukunde, Dierverzorging

421422423429

14 MTS (excl. Etaleren, Optiek), MLO (excl. Med.) MMO-Slagerij, MDGO-Mode en Kleding, KMBO/LLW Technisch en KMLO (excl. medisch)

15 Middelbaar Nautisch Onderwijs, KMBO/LLW/Bedrijfsopleidingen Rail-/Wegvervoer, Binnen-/Zee-/Luchtvaart

16 MDGO-AG/AB/SB/VP (Assistenten Gezondheidszorg (excl. Apothekersassistenten), Activiteitenbegeleiding, Sport en Beweging, Verpleging)

17 Middelbare Opleidingen Medisch Laboratoriumpersoneel, EEG-laboranten, Apothekersassistenten, Opticiens, Tand-/Orthopedische technici

18 Middelbare Opleiding Ziekenverzorging (o.a. IMEVO, EMGZ)

19 MEAO (excl. Bestuurlijk), MMO (excl. Horeca, Slagerij), MTS-Etaleren, KMBO/LLW Econ.-/Medisch-Administratief, AMBI

20 MEAO-Bestuurlijk, KMBO/LLW Notarieel, Juridisch, Fiscaal e.a. Bestuurlijke Richtingen

21 MDGO-SA/AW (Sociale Arbeid, Agogisch Werk), MBO-IW/SD/CW (Inrichtingswerk, Sociale Dienstverlening, Cultureel Werk), Documentatie-opl.

22 MDGO-VZ/CCD (Verzorging, Civiele \& Consumptieve Diensten), INTAS, KMBO/LLW-Verzorging

481484486

23 MMO-Horeca, MDGO-UV (Uiterlijke Verzorging), KMBO/LLW/Cursussen Horeca-, Kappers-, Schoonheidsverzorgingsbedrijf 
Code

ROA Omschrijving

24 Lagere Politieschool, Middelbaar Onderwijs Land-, Luchtmacht, Marine (KMS, KKSL), Brandweeropleidingen (niet officier)

26 Pedagogische Academie Basisonderwijs (PABO), Nieuwe Lerarenopleiding (NLO), Academie voor Lichamelijke Oefening (ALO), Praktijkdocenten HBO

27 Hogere Tolk- en Vertalersopleidingen (incl. Congrestolk)

28 Hogere Theologische Opleidingen Pastoraal Werker, Priester, Bijbels Theologische Vorming, Geestelijk Raadsman/-vrouw

29 Hogere Land-, Tuin-, Bosbouw- en Cultuurtechnische school, Milieuhygiëne (HTS, HAS)

30 Hoger Laboratoriumonderwijs, Hoger Statistiekonderwijs

31 HTS e.a. Hoger Technisch Onderwijs

32 Hoger Nautisch (Loods, Scheepswerktuigkunde) en Luchtvaart (Piloot, Verkeersleider) Onderwijs, Verkeers-/Vervoerskunde, Hogere PTT-opleiding

33 HBO-Verpleging, Verloskunde, Fysiotherapie, Logopedie, Muziektherapie, Manuele en Bewegingstherapie (Heil, Mensendieck, Cesar) e.d.

34 Hoger Medisch en Klinisch-Chemisch Laboratoriumonderwijs, Hogere Opleidingen Radiologisch en Röntgenlaborant, Optometrie, Audiologie

35 HBO-Diëtetiek/Voedingsleer

36 HEAO (excl. Bestuurlijk, Juridisch) e.a. Hogere Economisch, Administratieve, Commerciële en Toeristische Opleidingen

37 Bedrijfstechniek e.a. Hogere Technisch-Economische en Actuariële Opleidingen

38 HEAO-Bestuurlijk/Economisch-Juridisch e.a. Hogere Bestuurlijke Opleidingen

39 Sociale Academie, HBO-Agogisch, -Welzijnswerk (HBO-B/J), -Journalistiek, Academie Mens \& Arbeid, Bibliotheek- en Documentatie-academie

40 Hogere Hotelschool e.a. Hoger Horeca Onderwijs

41 Academie voor Beeldende Kunsten en Industriële Vormgeving, Filmacademie, Toneel-, Kleinkunst- en Dansacademie, Conservatorium e.d.

42 Politie-academie (NPA), Hoger Onderwijs Landmacht (KMA), Luchtmacht (KLU), Marine (KIM), Brandweerofficier

44 Universitaire Lerarenopleiding, MO-B

45 Wetenschappelijk Onderwijs Letteren (Moderne en Klassieke Talen), Filosofie, Geschiedenis, Archeologie

46 Wetenschappelijk Onderwijs Theologie, Godgeleerdheid, Studie tot Predikant, Pastor, Rabijn

47 Wetenschappelijk Onderwijs Land-, Tuin-, Bosbouw, Cultuurtechniek, Bodemkunde en Milieuhygiëne

48 Wetenschappelijk Onderwijs (drs.) Wiskunde, Natuur-/Sterrenkunde, Scheikunde, Biochemie, Biologie (+ir.), Fysische Geografie, Meteorologie

49 Wetenschappelijk Onderwijs (ir.) (Werktuig)bouwkunde, Electro-/Civiele/Chemische Techniek, Informatica, Toegep. Wiskunde, Ind. Vormgeving
Code

SOI

491492493494

506

511

516

521522523529

531

536538539

541542543544549

551

552

554

561

562

566

571

583

586

591592593594

606

611

616

621622623629

636638639 
Code $\quad$ Code

ROA Omschrijving SOI

50 Wetenschappelijk Onderwijs Geneeskunde, Diergeneeskunde, Tandheelkunde 651

51 Wetenschappelijk Onderwijs Farmacie (Apotheker) 652

52 Wetenschappelijk Onderwijs (drs.) (Bestuurlijke) Informatica, (Algemene, Bedrijfs-, Fiscale) Economie, Accountancy, Bedrijfskunde

53 Wetenschappelijk Onderwijs Econometrie, Actuariaat, Bedrijfskunde (ir.)

54 Wetenschappelijk Onderwijs Rechtsgeleerdheid, Bestuurskunde, Academie Rijksbelastingen

55 Wetenschappelijk Onderwijs Sociologie, Psychologie, Sociale Geografie, Planologie, Rijksarchiefschool,

Voortgezette Sociale Academie

56 Kunstgeschiedenis, Muziek-, Theaterwetenschappen,

57 Hogere Krijgsschool, Luchtmachtstafschool, Marinestafschool 